WOODS HOLE OCEANOGRAPHIC INSTITUTION

Woods Hole, Massachusetts

In citing this manuscript in a bibliography the reference should be followed by the phrase: UNPUBLISHED MANUSCRIPT.

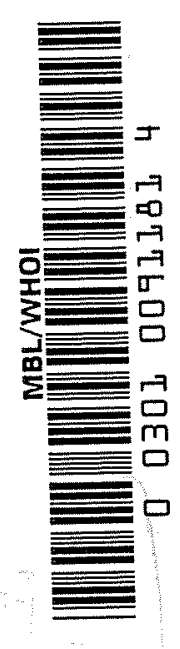

Reference No. $56-52$

MARINE METEOROLOGY

On the structure of trade-wind air below cloud

by

Joanne S. Malkus

Approved for public release;

distribution unlimited. Authority:

ONR 1tr 28 July 1977.

Reference: TAB 78-1 dated 6 Jan 1978.

AD 108219

Technical Report \#40

Submitted to the Office of Naval Research

Under Contract Nonr 1721(00)(NR-082-021)

August 1956

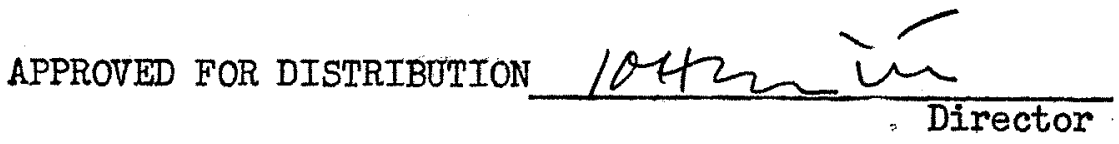




\title{
On the structure of trade-wind air below cloud
}

\author{
Joanne S. Malkus
}

\section{Abstract}

The moisture and temperature structure of the trade-wind mixed layer are compared under conditions of strong versus weak trade. The data used are two series of aircraft psychrograph soundings made over the ocean near Puerto Rico in early spring. The first in conditions of strong undisturbed trade and high zonal index (April $10-28,1946$ ) and the second under conditions of weak rather disturbed trade and low zonal index (March 18 - April 7, 1953).

The weak trade soundings show a less homogeneous moisture distribution and a less stable temperature lapse rate. Considerable variation in structure of the lowest air accompanies changes in the trade regime which may give rise to significant fluctuations in energy input at the source region for atmospheric circulations. The importance of wind stirring in the upward transfer of moisture is indicated, which may affect the formation of trade cumulus clouds. Further studies investigating the relation between air and ocean structure at their boundary are suggested by the evidence herein, which may relate to the formation of tropical storms. 


\section{INTRODUCTION}

In April 1946 the Wyman-Woodcock expedition to the Caribbean carried out 25 vertical airplane psychrograph soundings in order to study the structure of trade-wind air in the lowest $3 \mathrm{~km}$ over the sea. These records were analyzed in detail and reported on by Bunker, Haurwitz, Malkus, and Stomel (1949). These data were obtained during a period of relatively undisturbed strong trade with well developed low-level convection. During March-April 1953, another series of 9 soundings were obtained in the same region on an expedition made by the Woods Hole Meteorology group in collaboration with the Department of Meteorology, Imperial College, London. In contrast to the 1946 period, the latter soundings were obtained during relatively weak, disturbed trade and, during much of the time, poorly developed low-level convection.

A comparison of the structure and transports in the lower air between the two periods is now being undertaken. The first part of the results is presented here, namely a study of the moisture and temperature distribution below cloud base, and how it differed in the two cases. This work has been undertaken for primarily two reasons: the first to attempt to discover why convection was less well developed in the 1953 period and what part, if any, changed conditions below cloud may have contributed; and second, to compare the air structure and transports in the low levels under two different trade regimes in relation to fluctuations in the energy supply 
for larger scale phenomena such as tropical storms and the general circulation as a whole. The latter point requires some preliminary elucidation.

Riehl (1954) has suggested as a possible source of fluctuations in the hemispheric zonal index, variations in the trade-wind cell which is a main link in carrying the energy from the supply region to higher latitudes. The first step in the transport from the source, namely the lowest air over the tropical oceans, exerts an immediate and important control upon the amount, form, and distribution of the energy supplied. Previous studies of the trade-wind subcloud region have shown it to be about $600 \mathrm{~m}$ in depth (with extreme ranges from $300-1000 \mathrm{~m}$ ), the lower four-fifths consisting of a well-mixed layer, generally topped by a slightly more stable stratum just below cloud base. The present investigation concerns the mixed portion only. Since this layer is in nearly marginal static stability with only a slight upward decrease of mixing ratia, very small changes indeed in outgo of heat and moisture from its top or in income from the bottom may alter the fluxes by an order of magnitude or even change their direction.

Riehl has further suggested a possible delicate balance between evaporation, windspeed, and sea surface roughness. He cites evidence that the evaporation rate may double discontinuously when the wind speed rises above the critical value for whitecaps, namely $6-7 \mathrm{~m} / \mathrm{sec}$, which is very near the average speed of the trade winds. 
This would lead to considexable fluctuation in the energy input, since about $75 \%$ of it initially occurs in the form of latent heat. Fortunately the 1946 and 1953 observations fall on clearly different sides of the critical wind speed and the results may be examined with this suggestion in mind. This is done in Section IV after a brief comparison of the overall synoptic picture in the two cases and a discussion of the method of observation.

II. THE SYNOPTIC SITUATION IN THE WESTERN ATLANTIC TRADE DURING THE 1946 AND 1953 OBSERVING PERIODS

The period of April 10 - 28, 1946, was one of relatively strong undisturbed trade. The average (shipboard) wind speed on all observing days was $9.1 \mathrm{~m} / \mathrm{sec}$ and the sea was generally rough with whitecaps present. The trajectories of the air reaching the observing region (50 - 100 miles north of San Juan, Puerto Rico) were from north of east. The subtropical high pressure cell was well developed, elongated from east to west, and had a central pressure departing little from $1023 \mathrm{mb}$. Rather little flow across it occurred during the period. The time cross section for all observing days and a typical surface map are shown in Figures la and $2 \mathrm{a}$.

The period of March 18 - April 7, 1953 was one of weaker, more disturbed trade regime. The surface winds in the observing area averaged $5.7 \mathrm{~m} / \mathrm{sec}$ and no whitecaps were seen on seven of the 
nine days. The time cross section is shown in Figure $I B$ and a typical surface map in Figure 2B. They show that travelling disturbances were more intense at all levels than in the same period of 1946. Middle and high cloudiness are frequent in the 1953 time section, while none are reported on that of 1946. Relatively lower zonal index during the 1953 observations is suggested by Figures 1 and 2 and further by Figure 3. The latter is a plot of the central pressure of the subtropical high cell, which averaged less than $1017 \mathrm{mb}$ on all observing days and decreased markedly from the beginning to the end of the period. Not only did the zonal (easterly) wind component fall off, but it is likely that the meridional trade-wind cell was concomitantly running down. The equatorward component of flow disappears and actually reverses between March 30 and April 5, and the trajectories of the air. reaching San Juan are from south of east.

It may thus be considered that the 1946 soundings show air structure typical of strong circulation (for the location and season) and the 1953 soundings show the features of weak circulation at the same place and season. They will therefore be designated as series $H$ and $I$ respectively throughout the rest of this report.

III. METHOD OF OBTAINING THE DATA USED

In each case the soundings were taken by a revised version of the M. I. T. psychrograph mounted on a PBY aircraft. Dry and 
wet-bulb temperatures were recorded as the aircraft spiralled upward at about $200 \mathrm{ft} / \mathrm{min}$, a slow enough rate of climb for lag-free readings to be obtained. The spirals were about two miles in diameter and in series L they were frequently made around smoke flares which had been dropped to determine the surface wind direction. Additional wind information was obtained from the Imperial College meteorology group which made double theodolite pilot balloon observations from Anegada island $\left(18^{\circ} 5^{\circ} \mathrm{N}, 64^{\circ} 20^{\circ} \mathrm{W}\right)$ which is 120 miles east-northeast of San Juan and generally within 20 miles of the observing area. The 1946 (series H) spirals were in the vicinity of a surface vessel which supplied the wind information.

For series I a wide-angle time lapse motion picture camera was used from the nose of the aircraft during 211 soundings. This made it possible to determine the location of the spirals ralative to cloud groups and to assess the state of the sea surface. For series $H$ this was done from the aireraft and ship observers notes. The accuracy of the obserrations and their method of reduction has been described in detail in the paper by Bunker et al (1oc。cit., 1949) in which the series H soundings are published. The series $L$ soundings appear at the back of this report, where temperature, mixing ratio, virtual and potential temperature are tabulated as functions of (true) altitude and pressure. 
IV. INFORMATION GAINED FROM THE SOUNDINGS AND COMPARISON BETWEEN THEM

In series $H$, the temperature lapse rate in the mixed layer was always slightly subadiabatic and its mixing ratio hovered about a constant value, dropping only about $0.4 \mathrm{gm} / \mathrm{kgm}$ from the bottom of the layer to the top. Three questions were raised by these data: First, concerning the magnitude and direction of the sensible heat flux, which according to classical turbulence ideas should have been downward. Recently the existence of countergradient heat flows has been hypothesized and confirmed observationally (Bunker, 1956). Although the sensible heat accumulation by the lower trade is only about $25 \%$ that of the latent, the heating has been shown (Riehl and Malkas, 1956) to be vital in the maintenance of the circulation. Thus the direction and size of its flux in the lowest layers remains an important unresolved question. The second question concerned the origin of trade cumulus clouds. The subadiabatic lapse rate precluded their origin in Bénard-type convection cells, while roots in cloudscale thermals were eliminated by horizontal runs determining drafts, virtual temperature, and turbulence below cloud base. A clue to the mechanism of origin of cloud groups was provided by the 1946 (series H) data where the lifting condensation level of the air in the mixed region was calculated and compared with the thickness of the layer. In cloudy areas, the top of the mixed layer reached nearly to the condensation level, while in clear 
zones away from clouds it fell considerably short of that height. Some recent airborne sea surface temperature measurements (Malkus, 1956) have suggested that warmer spots in the sea surface may give rise to weak convergences in the wind field sufficient to account for local thickening of the mixed layer of this magnitude and scale. Finally, a question concerning the mechanism of maintenance of convective-turbulence in the mixed layer itself was raised, and the relative roles of buoyancy and wind stirring therein. The vertical transports in the lower trades are undoubtedly a combination of turbulent shear flow and thermal turbulence in a fluid heated from below. The relative importance of these and the effect of their interaction has not been assessed. The series $I$ soundings have been analyzed and compared with those of series $H$ with these questions in mind. Although it is not yet possible to give definite answers to any of them, nor to make an experiment isolating a single factor alone, such as wind strength or sea surface roughness, the differences in subcloud air structure in the two periods suggest that important fluctuations in energy input and transfer accompany changes in flow regime in this critical source region. The nature and magnitude of these differences give some clues as to their origin and possible effects upon other parts of the trade-wind atmosphere.

A sumary of the major features of the mixed layer for series $I$ is presented in Table 1. A comparison of the $H$ and $L$ series appears in Table 2, subdivided into clear and cloudy area 
soundings. The last five columns (right) of Table 1 were obtained by calculations from the soundings as follows: Plots of temperature, virtual temperature, and mixing ratio against height were made and the lapse rate of each determined graphically and checked by the method of least squares. The height, $h$, of the mixed layer was determined, as by Bunker et al. for series $H$, by picking the height at which the mixing ratio lapse rate increased suddenly. This level was usually well defined and was further confirmed in most cases by a concomitant stabilization of temperature lapse rate. The lifting condensation level was found from a tephigram, using the mean properties of the mixed layer air.

The lapse rate of virtual temperature averaged $4 \%$ greater than the temperature lapse rate for series $L$, but in no case went over to superadiabatic when the temperature lapse rate was subadiabatic. In contrast to series $\mathrm{H}$, however, one case of superadiabatic mixed layer was found in series $I$, namely that of the sounding of April 2. This was a day of particularly light wind, and the nose camera film showed the calmest sea of the period. A rough calculation sheds light on the role of buoyancy. In the case of the average lapse rate of virtual temperature, T*, it may be show that buoyant bubbles leaving the sea surface with virtual temperature excesses of $0.6-0.8^{\circ} \mathrm{C}$ could rise through about half the depth of the mixed layer before losing their buoyancy at normal rates of mixing. When the lapse rate is $5 \%$ superadiabatic, 
as in the case of April 2, they could rise through its entire depth before losing 211 buoyancy.

Prior to comparison of the two series using Table 2, it should be pointed out that of the 25 series $H$ soundings, 16 were made in clear areas and 9 in cloudy, and generally one or more both clear and cloudy area soundings were made on a single observing day. Furthermore, wind and synoptic conditions varied little through the $\mathrm{H}$ period so that Table 2 essentially presents for series $\mathrm{H}$ a comparison between clear and cloudy area soundings at a single time. The temperature difference in the last column therefore probably means that at $11 \mathrm{~m}$ the temperature was slightly warmer in cloudy zones than in clear zones. In series I soundings were made in cloudy areas whenever any such were easily accessible to the aircraft. The five soundings entitled "clear area" were made on days when oceanic cloud groups were small and far between or absent altogether.* Thus in series $\boldsymbol{L}$ we are comparing "good trade cumulus days" versus "few or no trade cumulus days". Except for the very last day, namely April 7, the good trade cumulus days were confined to the beginning of the period, and in all cases confined to days when the flow was

*On April 1 enormous cumulonimbus buildups were visible about 70 miles north of the observing area. The ordinary trade cumulus groups were, however, rather widely spaced and not well developed。 
from east or north of east. The days of poor convection (except for the somewhat anomalous case of April 1) were those in which the flow was from a direction well to south of east. This is reflected in the last two columns of Table 2, showing a wind averaging $57^{\circ}$ more southerly and an $11-\mathrm{m}$ air temperature $1.1^{\circ} \mathrm{C}$ warmer on poor days for convection.

The most significant difference between the $H$ and $L$ subcloud air lies in the moisture distribution. The air is wetter at the surface and drier at the top in series $\mathrm{L}$ and the mixing ratio lapse rate exceeds that of $H$ by an average factor of 3.5 ! The character of the vertical moisture structure was quite different in the two series and was even recognizable on the plots of mixing ratio against height. A typical example from each series is reproduced in Figure 4. It appears that in the $L$ series the water vapor just was not getting pumped up through the subcloud layer and it therefore accumulated in the lowest levels. This may, in turn, have inhibited further evaporation. From the effect of the higher relative humidity alone, the evaporation in series $L$ would have only been $80 \%$ of that of series $\mathrm{H}$, and if Riehl's suggestion is correct it may actually have been less than 50\%. A possible important oceanographic consequence of such a "stopping down" of evaporation is discussed in the concluding paragraphs.

That turbulence in the subcloud layer was subnormal in series L has been suggested by Bunker (1955) from his low values 
of shearing stress, turbulent velocities, and eddy viscosities. What proportion of this subnormality of turbulence is attributable to reduced wind stirring and what proportion to diminished heating from below as a result of the changed air trajectories cannot be assessed from these data. The importance of wind stirring in regulating the features of low-level trade wind air is suggested, however, by two further calculations. The first is presented in the third column from the left in Table 2 which gives the difference in height between the lifting condensation level, LCL, and the top of the mixed layer, H, broken down again into clear and cloudy area categories. In the series $\mathrm{H}$ cloudy areas the top of the mixed layer averaged $87 \mathrm{~m}$ below the height

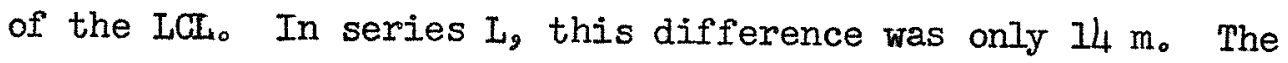
buoyancy available to bubbles was nearly the same in both cases and, if anything, greater in L. It seems Iikely, therefore, that the greater stirring produced by the wind was responsible in $\mathrm{H}$ for subcloud eddies being carried $87 \mathrm{~m}$ above the top of the mixed layer to reach saturation. In $\mathrm{L}$ the cloudy region ECL and the top of the mixed Iayer are, within observational error, equal so that no overshooting is indicated. Finally, Table $I$ shows that during the $I$ period large variations in wind speed and mixed layer lapse rate occurred and an inverse relation between these variables is indicated. A correlation between wind speed and temperature lapse rate was 
computed and came out -0.68 even when corrected for the small number of observations. Despite the doubtful representativeness of island winds, this result is extremely suggestive that the upward transports of heat and moisture are greatly dependent upon wind stirring and may become considerably deranged after prolonged periods of subnormal winds. The reality of this inverse relation between subcloud stability and wind speed is further argued by examination of the average structure of the low-level Pacific trade (Riehl et al., 1951). As the current flows southwestward and accelerates, the subcloud lapse rate goes over gradually from slightly superadiabatic at latitude $32^{\circ}$ to subadiabatic by latitude $21^{\circ}$, despite constant or even increased heating from below. The average windspeed increases by about $0.8 \mathrm{~m} / \mathrm{sec}$ and the positive windshear doubles during that travel. Further tests of this relation will be possible in the Atlantic trade following the establishment of a surface vessel making wind and temperature soundings on a routine basis。

\section{CONCLUDING REMARKS}

Riehl's suggestion that important fluctuations in the atmospheric energy supply accompany changes in trade regime has received observational support at the first step, namely that from the ocean surface to the lowest air and upward through the first few hundred meters. The importance of wind stirring and/or 
sea surface roughness is indicated. One reas on why the period of March 30 - April 7, 1953 was poor for convection in the observing area has been found: namely on "poor cloud days" the mixed layer top fell short of the condensation level by more than $200 \mathrm{~m}$. Oceanic warm spots at least $0.4^{\circ} \mathrm{C}$ in amplitude would be required to thicken the layer by that amount (Malkus, 1956) and so far ones that pronounced have rarely been observed in the open sea. To find out why the few clouds that did form during that period were poorly developed we plan a further comparison of the upper levels of the series $L$ and $H$ soundings. Changes such as described here in the low-level trade wind air from periods of high to low index may have important oceanographic consequences which may, in turn, play a role in controlling the formation of tropical storms. For example, if over a given source region evaporation is cut by a factor of two for a period of 90 days the sea surface will be about $1.2^{\circ} \mathrm{C}$ warmer than under normal evaporation, even if the heat loss is distributed through an ocean layer $100 \mathrm{~m}$ deep. This temperature rise would be doubled if the decreased wind stirring permitted the oceanic mixed layer to shrink to half that depth. A $2^{\circ} \mathrm{C}$ temperature difference in the sea surface may be critical in the formation and development of a hurricane.

Two types of study are suggested by this reasoning, which at present is little beyond the speculation stage: 
First, a synoptic study comparing the number and intensity of storms forming in a given source region to the strength of the trades an appropriate distance up-current for the preceding 3 months and a comparison of the total number and intensity of hurricanes in a given season in the Atlantic or Pacific trade with the overall strength of that trade throughout the preceding spring. Second, a combined oceanographic and meteorological observation program relating the character of the mixed layers of ocean and atmosphere, their interaction ahd how it affects and is affected by larger scale processes. Such a program is planned by this Institution utilizing the Research Vessel CRAWFORD together with the aircraft.

Acknowledgments: The writer wishes to acknowledge the enormous contribution by her colleague, Mr. Andrew Bunker, whose studies of the trade-wind mixed leyer have set the precedent for this work and which promise in the future to resolve many of the questions left open at the present time。 
- 16 -

\begin{tabular}{|c|c|c|c|c|c|c|c|c|c|c|c|}
\hline 芫 & 日 & 8 & i & 话 & 鹪 & 品 & 8 & 융 & 望 & 8 & 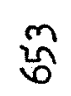 \\
\hline 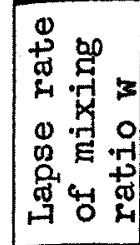 & 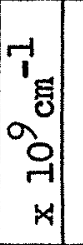 & నे & $\Sigma$ & $\stackrel{\infty}{\sim}$ & $\stackrel{\infty}{\sim}$. & $\stackrel{\vec{\sim}}{\stackrel{0}{0}}$ & 각 & $\underset{r}{\stackrel{m}{r}}$ & $\tilde{m}$ & $\stackrel{\stackrel{2}{r}}{r}$ & $\overrightarrow{\stackrel{0}{0}}$ \\
\hline 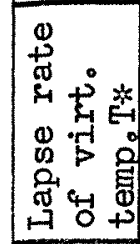 & $\begin{array}{l}\text { E } \\
8 \\
0 \\
0 \\
0\end{array}$ & $\stackrel{\infty}{\infty}$ & $\Sigma$ & 용 & б. & $\stackrel{\infty}{\circ}$ & $\begin{array}{l}2 n \\
0 \\
r\end{array}$ & a & $\because$ & $\stackrel{\infty}{\circ}$ & $\vec{\sigma}$ \\
\hline 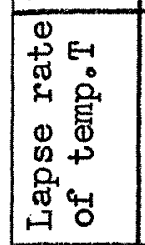 & 혀 & के & ${ }_{\alpha}^{m}$ & 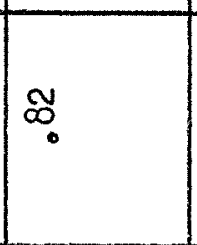 & $\stackrel{2 n}{\alpha}$ & $\stackrel{2 n}{\circ}$ & $\begin{array}{l}\text { J } \\
\text { - }\end{array}$ & 용 & 5 & 형 & ฉू \\
\hline 도 & 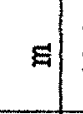 & $\stackrel{\circ}{\circ}$ & 只 & 윳 & $\underset{m}{\infty}$ & 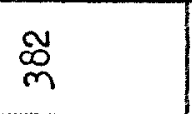 & 온 & 8 & 吕 & 8 & $\hat{n}$ \\
\hline $\begin{array}{l}\text { ฐ } \\
\text { జ. }\end{array}$ & & 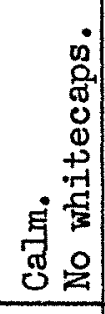 & 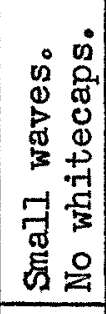 & 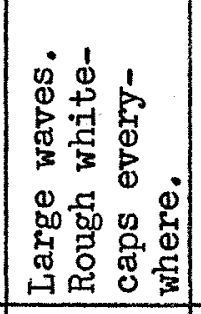 & 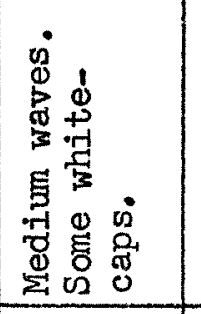 & 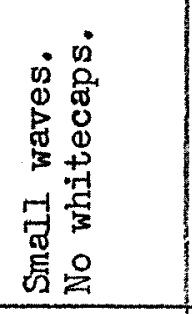 & 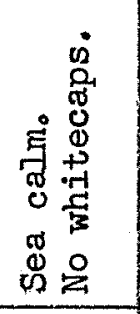 & 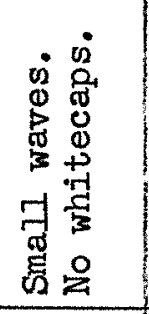 & 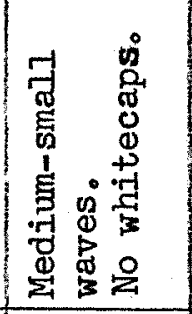 & 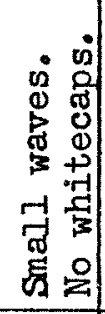 & \\
\hline 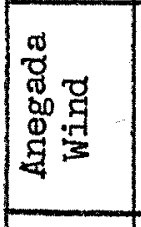 & $\begin{array}{l}0 \\
\text { घ. } \\
\text { हो } \\
0\end{array}$ & $\begin{array}{l}+ \\
\stackrel{\infty}{H}\end{array}$ & $\begin{array}{l}n \\
n\end{array}$ & $\begin{array}{l}\text { ㅇ } \\
2 \\
\infty\end{array}$ & $\begin{array}{l}\text { nn } \\
\text { 억 } \\
\end{array}$ & $\begin{array}{l}+ \\
0 \\
7\end{array}$ & $\begin{array}{l}+ \\
\stackrel{ }{+}\end{array}$ & $\begin{array}{l}\circ \\
\text { 옥 }\end{array}$ & $\begin{array}{l}2 n \\
\stackrel{2}{2} \\
0 \\
\text { न }\end{array}$ & $\begin{array}{l}n \\
2 \\
2 \\
2\end{array}$ & $\begin{array}{l}\text { in } \\
\text { Ln } \\
\text { L }\end{array}$ \\
\hline 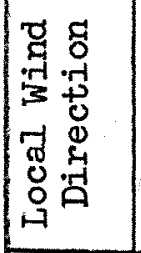 & 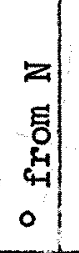 & $\stackrel{m}{\sim}$ & $\infty$ & 응 & 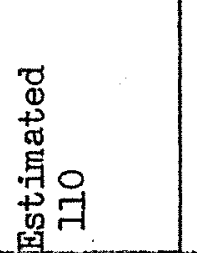 & $\stackrel{P}{r}$ & 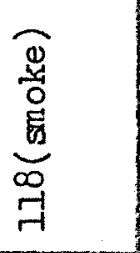 & 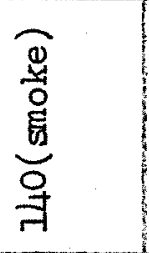 & & 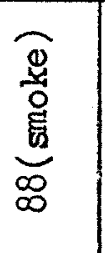 & 穴 \\
\hline $\begin{array}{l}1 \\
0 \\
-11 \\
+4 \\
0 \\
0 \\
0 \\
0 \\
7 \\
\end{array}$ & & 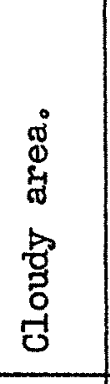 & 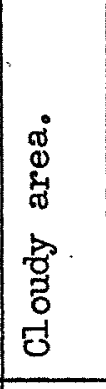 & 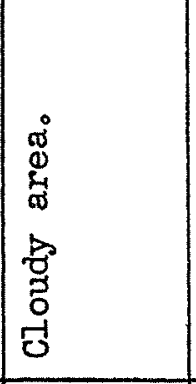 & 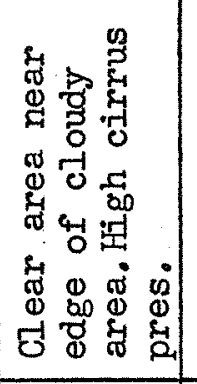 & 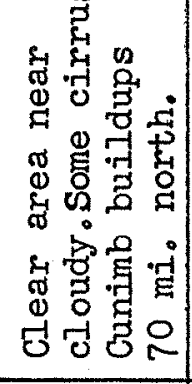 & 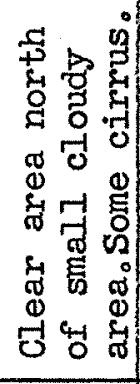 & 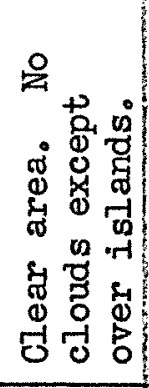 & 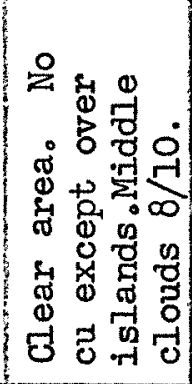 & 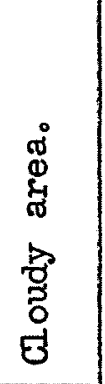 & \\
\hline 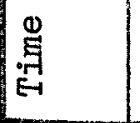 & 点 & 瓷 & 㝵 & $\begin{array}{l}n \\
\overrightarrow{7} \\
7\end{array}$ & 苟 & 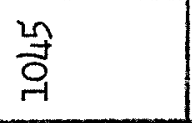 & 凊 & $\begin{array}{l}0 \\
\text { 국 }\end{array}$ & $\begin{array}{l}8 \\
7 \\
7\end{array}$ & $\begin{array}{l}\text { 옹 } \\
\text { م }\end{array}$ & \\
\hline 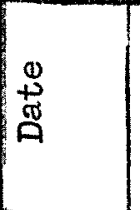 & & 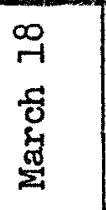 & 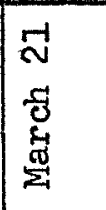 & 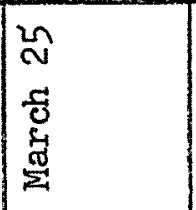 & 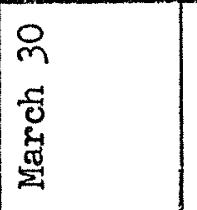 & 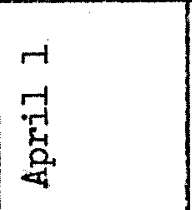 & $\begin{array}{l}N \\
-7 \\
-1\end{array}$ & 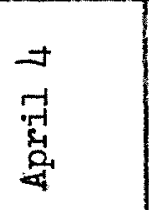 & $\mid \begin{array}{l}n \\
-1 \\
7 \\
0 \\
0\end{array}$ & \begin{tabular}{l}
- \\
7 \\
\multirow{2}{4}{} \\
\multirow{4}{4}{}
\end{tabular} & 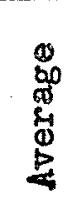 \\
\hline
\end{tabular}




\begin{tabular}{|c|c|c|c|}
\hline$\underset{E-1}{\stackrel{E}{G}}$ & 0 & 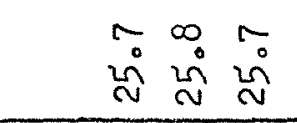 & 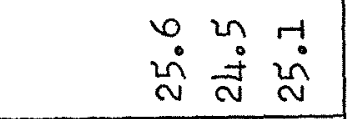 \\
\hline 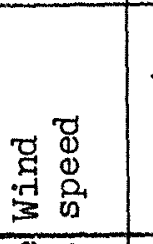 & $\begin{array}{l}0 \\
0 \\
0 \\
0 \\
2 \\
2 \\
0 \\
0 \\
\end{array}$ & $\begin{array}{lll}a & 21 & -1 \\
\infty & 0 & 0 \\
\infty & 0 & 8\end{array}$ & 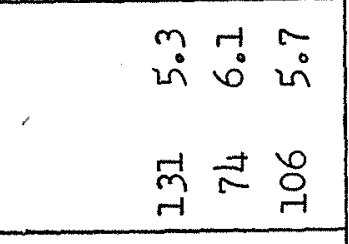 \\
\hline 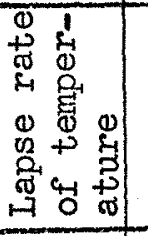 & $\begin{array}{l}8 \\
8 \\
0 \\
0 \\
0 \\
\end{array}$ & \& & 용 용 \\
\hline 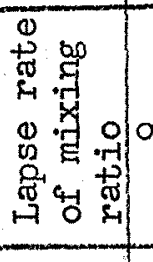 & 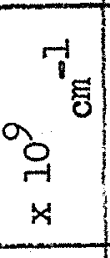 & $\begin{array}{ccc}\vec{a} & 0 & \infty \\
0 & \stackrel{0}{+} & \text { ก } \\
1 & 1 & 1\end{array}$ & 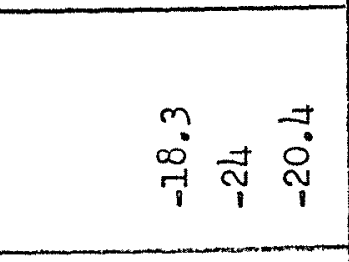 \\
\hline 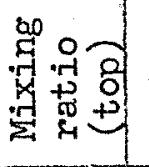 & 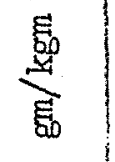 & 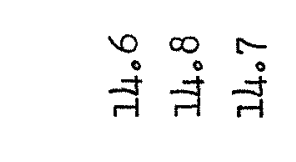 & 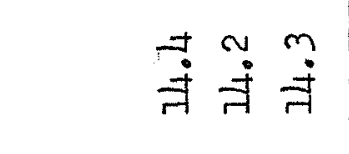 \\
\hline 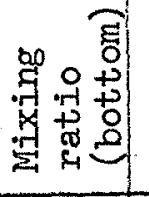 & 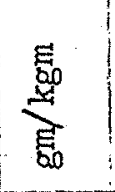 & 우요 & 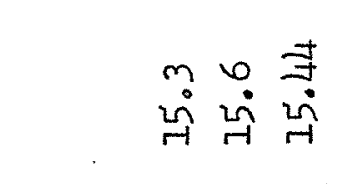 \\
\hline 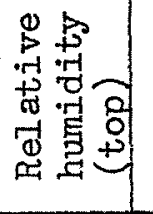 & oe & ஃ 대 \& & 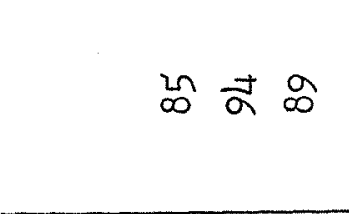 \\
\hline 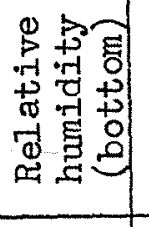 & $\infty$ & 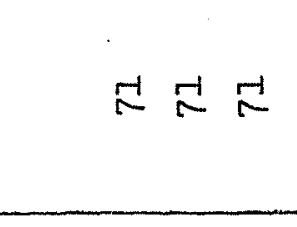 & $\stackrel{1}{\sim}-1 \stackrel{\infty}{\sim}$ \\
\hline : & $\Xi$ & 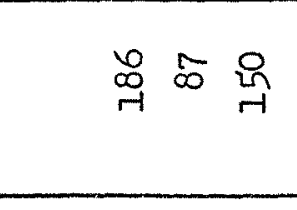 & 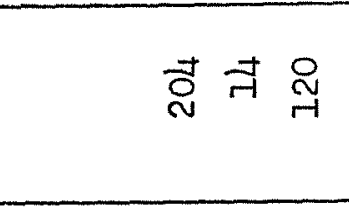 \\
\hline$\therefore$ & $\Xi$ & 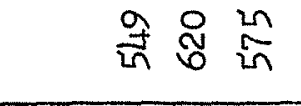 & $\begin{array}{l}0 \\
g \\
g \\
\end{array}$ \\
\hline & & 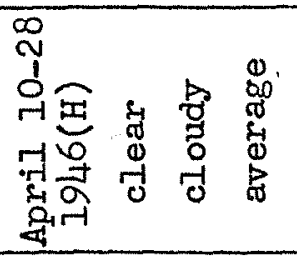 & 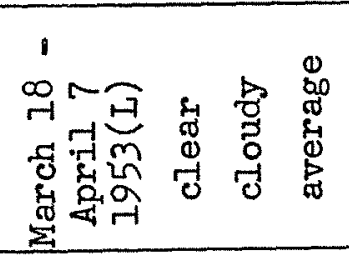 \\
\hline
\end{tabular}




\section{$\underline{\text { References }}$}

Bunker, A. F., B. Haurwitz, J. S. Malkus and H. Stommel, 1949: Vertical distribution of temperature and humidity over the Caribbean Sea. Pap. Phys. Ocean. Meteor. Mass. Inst. Tech. and Woods Hole Ocean. Inst., II, No.I; $82 \mathrm{pp}$.

Bunker, A. F., 1955: Turbulence and shearing stresses measured over the North Atlantic Ocean by an airplane-acceleration technique. J. Met., 12, $445-455$.

Bunker, A. F., 1956: Measurements of countergradient heat flows in the atmosphere. Australian Jo of Phys., 9, $133-143$.

Malkus, Joanne S., 1956: Trade cumulus cloud groups: Some observations suggesting a mechanism of their origin. Unpublished manuscript submitted to Tellus.

Riehl, H., 1954: Variations of energy exchange between sea and air in the trades. Weather, 2, 335 - 340.

Riehl, H., T. C. Yeh, J. S. Malkus and N. E. LaSeur, 1951: The northeast trade of the Pacific Ocean. Q. J. Roy. Met. Soc., 77, $598-626$.

Riehl, $H_{0}$, and Jo So Malkus, 1956: On the heat balance and maintenance of circulation in the trades. Tech. Rep't. submitted to the Office of Naval Research under Contract N6ori-02036 with the Univo of Chicago and Contract No. Nonr 1721(00) with the Woods Hole Ocean. Inst. $14 \mathrm{pp}$. 


\section{Titles for Figures}

Fig. 1. Time cross sections for the two observing periods April 10 - 28, 1946 (H), Fig. Ia, and March 18 - April 7, $1953\left(I_{r}\right)$, Fig. Ib covering observation days only. Upper winds are RAWINS. A short barb indicates a speed of $5 \mathrm{mph}$, a long barb $10 \mathrm{mph}$. Surface winds are in Beaufort scale. The hatched region is the moist layer, the top of which is represented by a dotted line. The base of the westerlies is indicated by a dashed line. The greater strength of disturbances in the 1953 (L) period is suggested by more cloudiness and in particular more middle and upper clouds.

Fig. 2. Typical surface charts for the two observing periods. In each case the heavy solid line denotes a polar trough. Figure 2a is the chart for April 12, 1946, 1230 GCT chosen as typical of period $H$ and Figure 26 is the chart for March 29, 1953, 1830 GCT chosen as typical of period Lo Note the weaker subtropical high cell and relative north-south elongation of pressure systems on the latter.

Fig. 3. Plot of the central pressure of the subtropical high cell during the 1953 (I) observing period as a function of time. Taken from the 1830 GCT surface chart daily.

Fig. 4. Typical plots of mixing ratio against height for sounding series $\mathrm{H}$ (left-hand curve) and $\mathrm{L}$ (right-hand curve). The 
curve for series $H$ was plotted from the April 10 (1524 IST) 1946 sounding and the curve for series $\mathrm{L}$ was plotted from the April 2, 1953, sounding. Both soundings were made in the clear and show nearly equal depth of the mixed layer (solid horizontal line). The average moisture lapse rate in the $I$ case is 2.5 times that of the $H$ case and its fluctuations about the average are much less. 

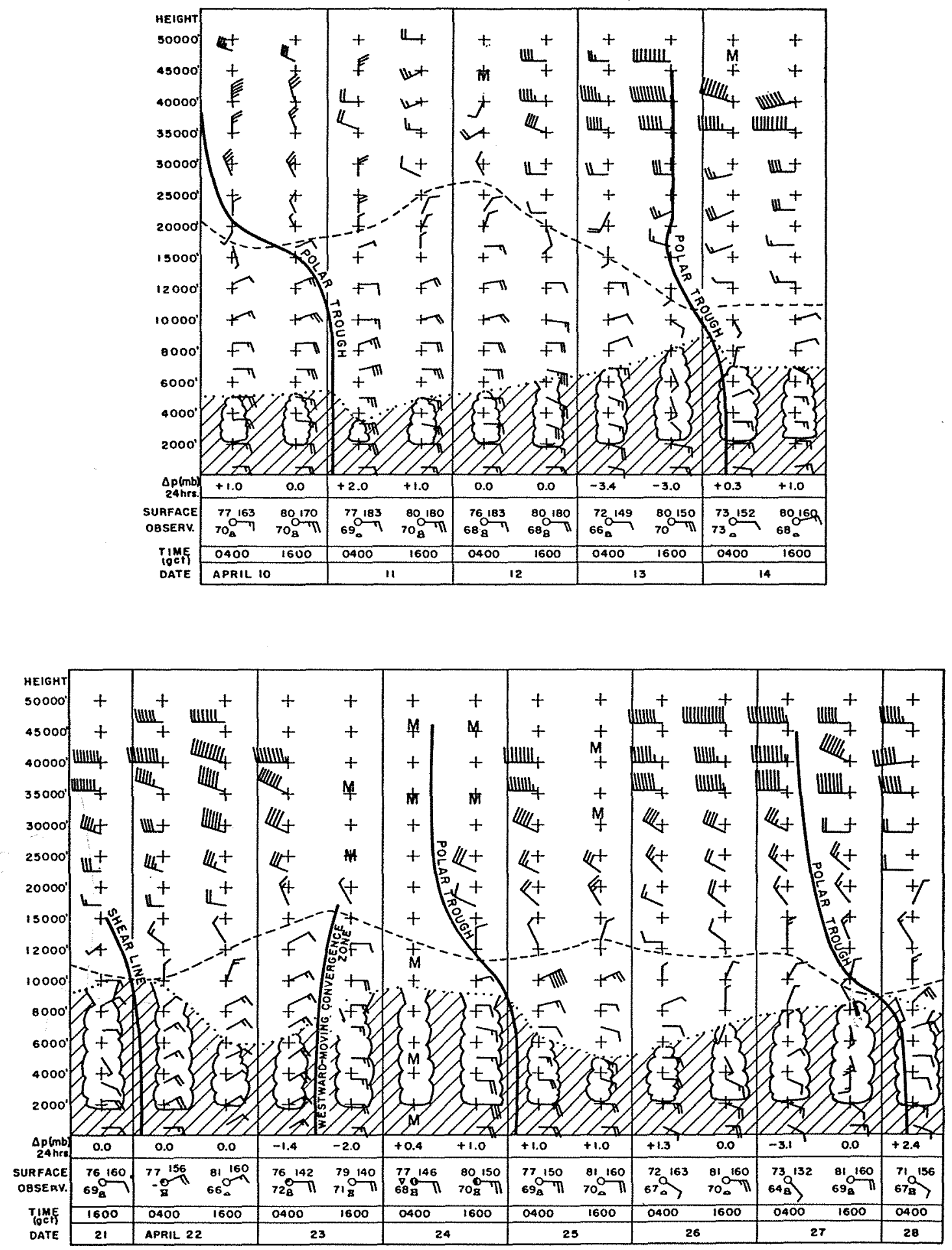

FIG. IA 

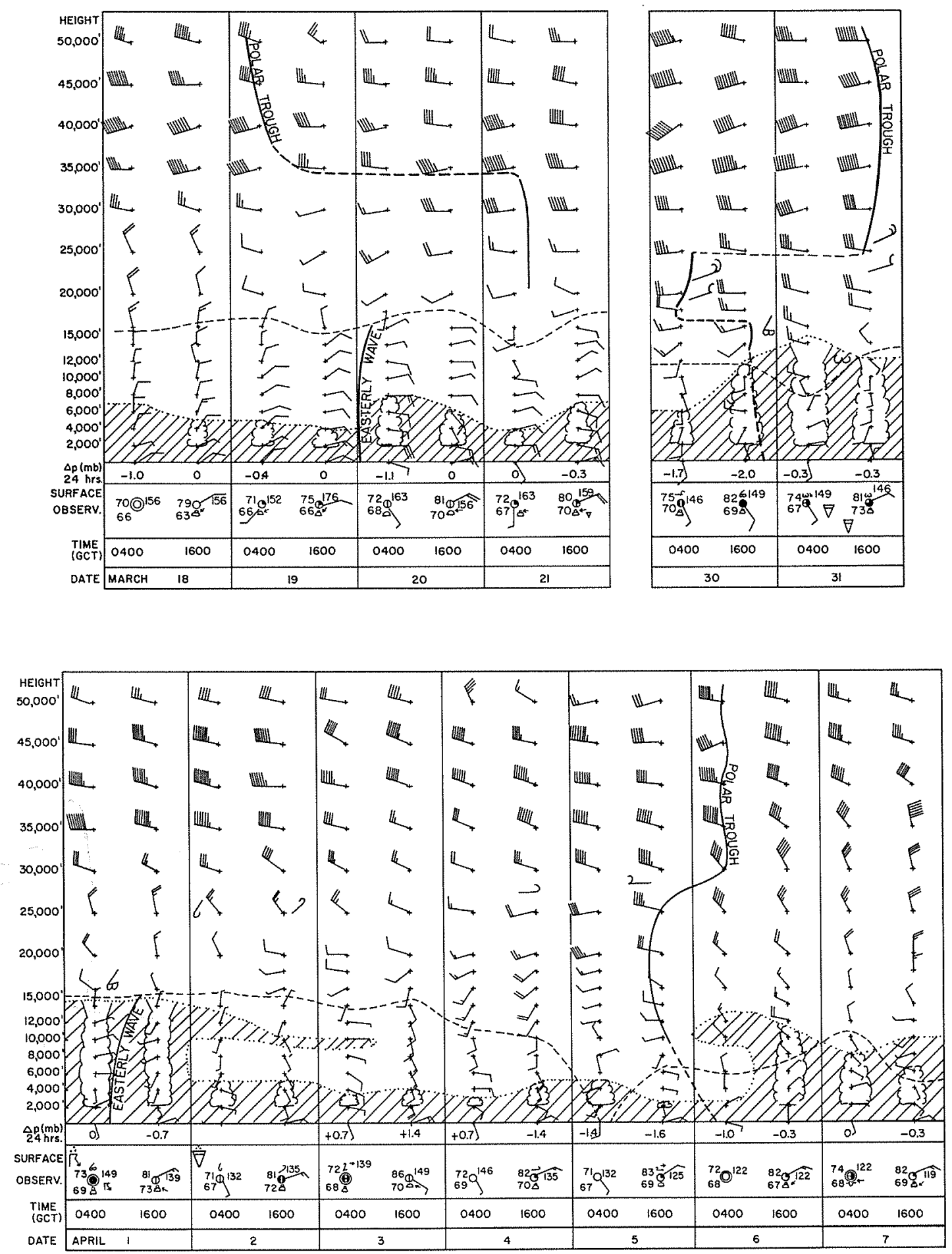


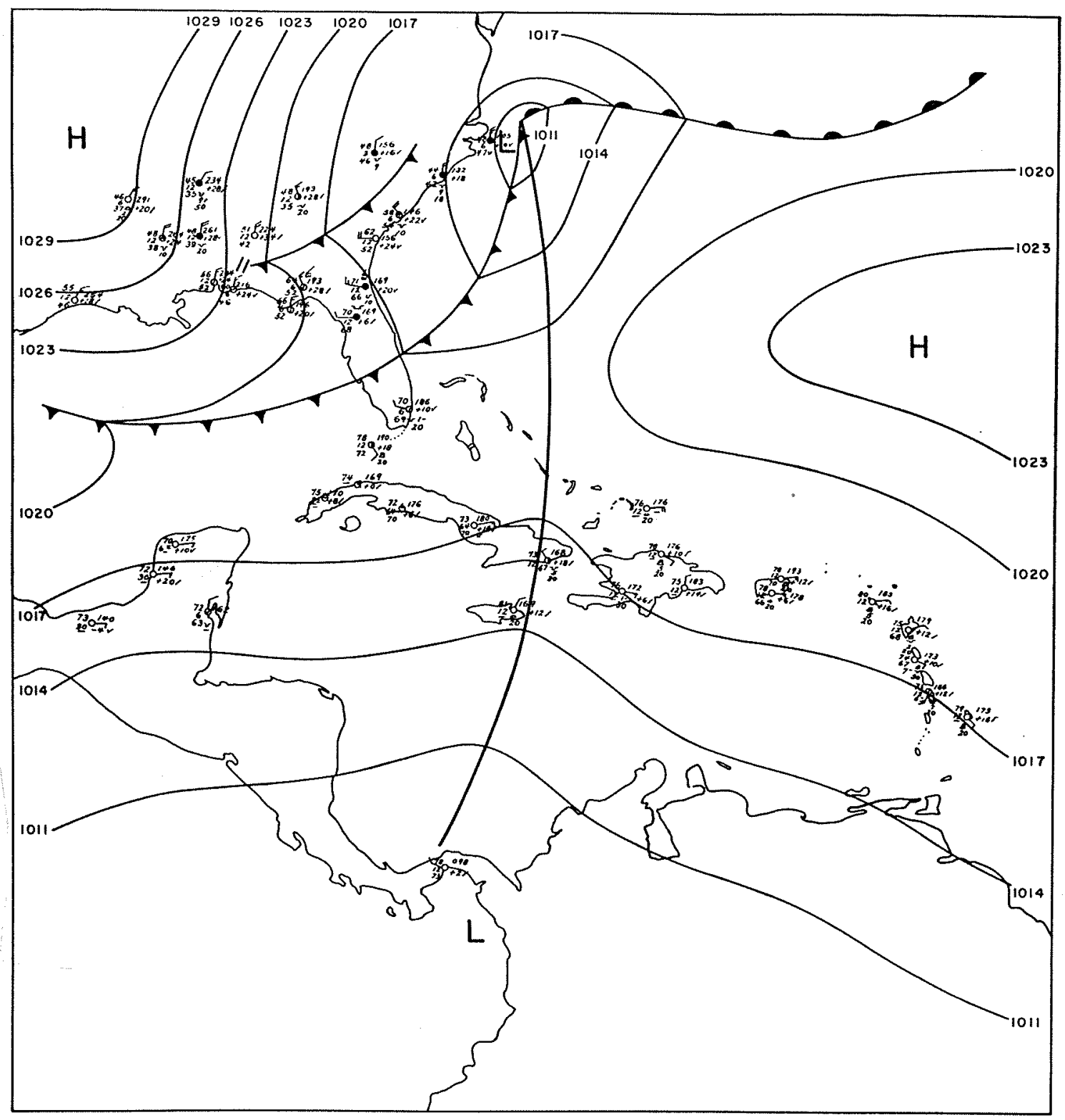

FIG. 2A 


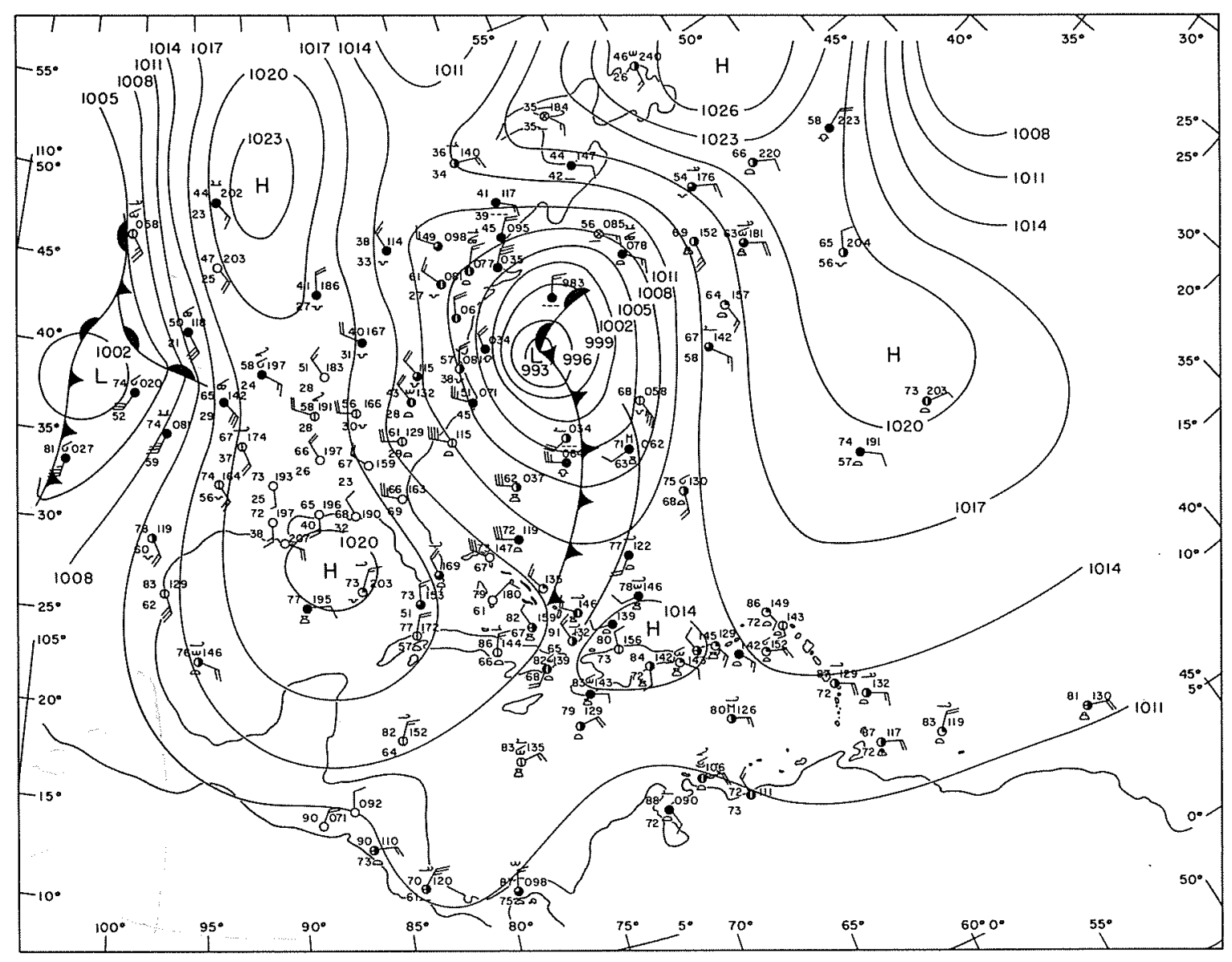

FIG.2B 


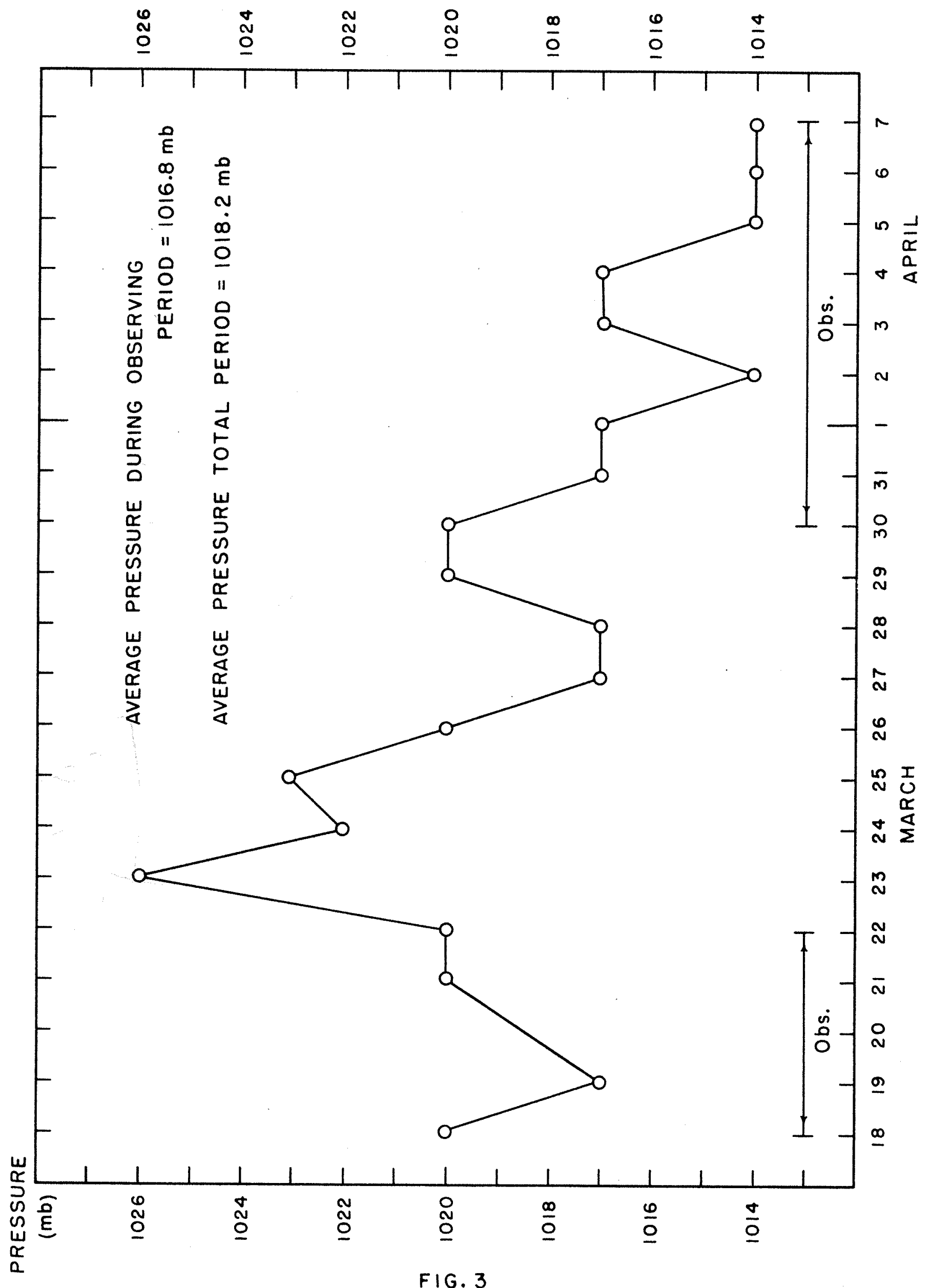

FIG. 3 


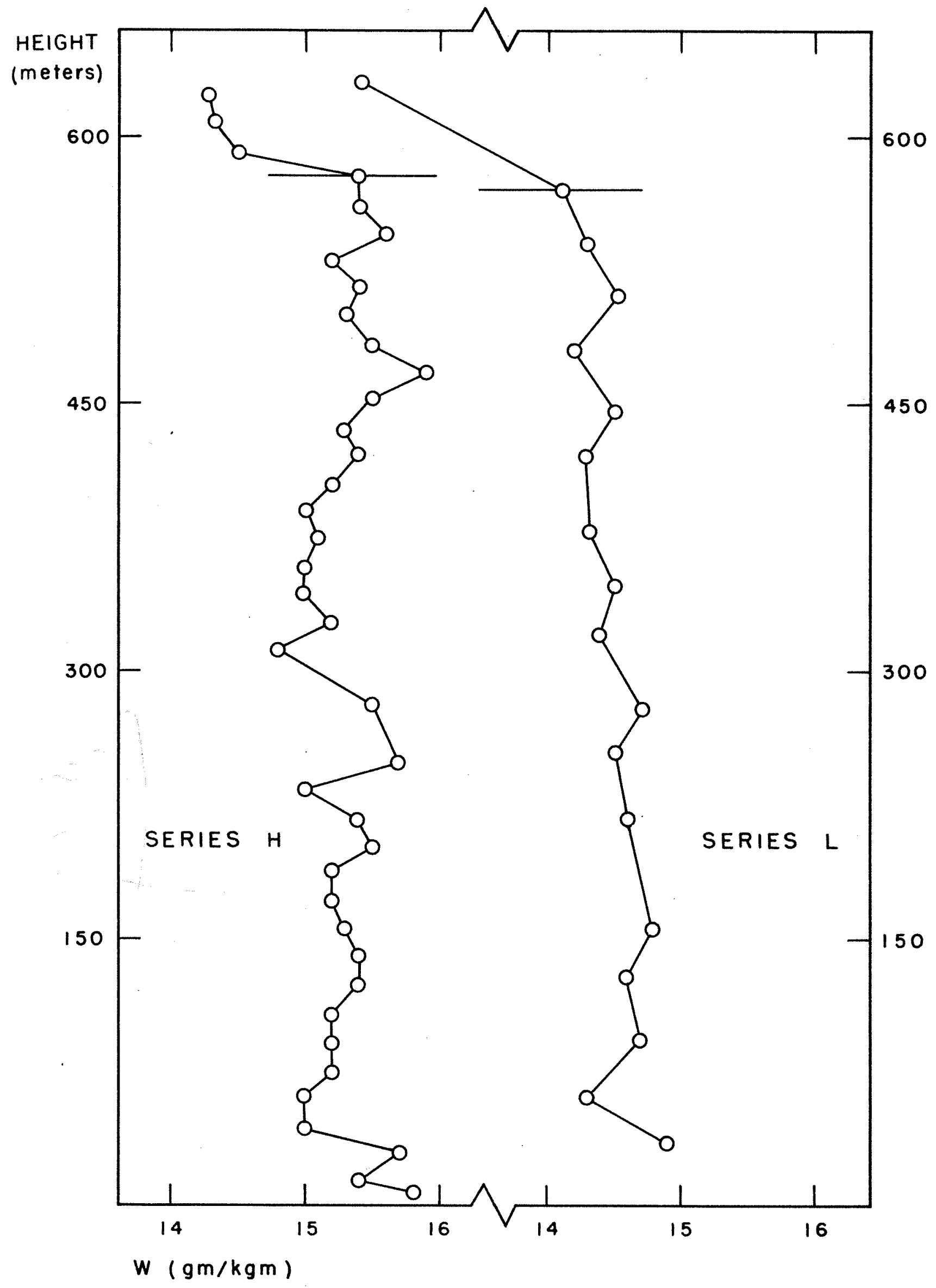

FIG. 4 


\section{Soundings - Reduced and Tabulated}

Temperature, $\mathrm{T}\left({ }^{\circ} \mathrm{C}\right)$, mixing ratio, $\mathrm{w}(\mathrm{gm} / \mathrm{kgm})$, virtual temperature $T *\left({ }^{\circ} A\right)$ and potential temperature $\theta\left({ }^{\circ} A\right)$ are presented in the following tables as functions of pressure $p(\mathrm{mb})$ and height (true)

h (m) for each of the nine 1953 soundings.

The times and locations of the soundings, the Anegada surface winds and the ambient cloud character are given in the heading to each. 
March 18, 1953. 1450 LST. Sounding in cloudy area.

Wind $18^{\circ}, 4 \mathrm{~m} / \mathrm{sec}$ Location: 5 miles north of Anegada.

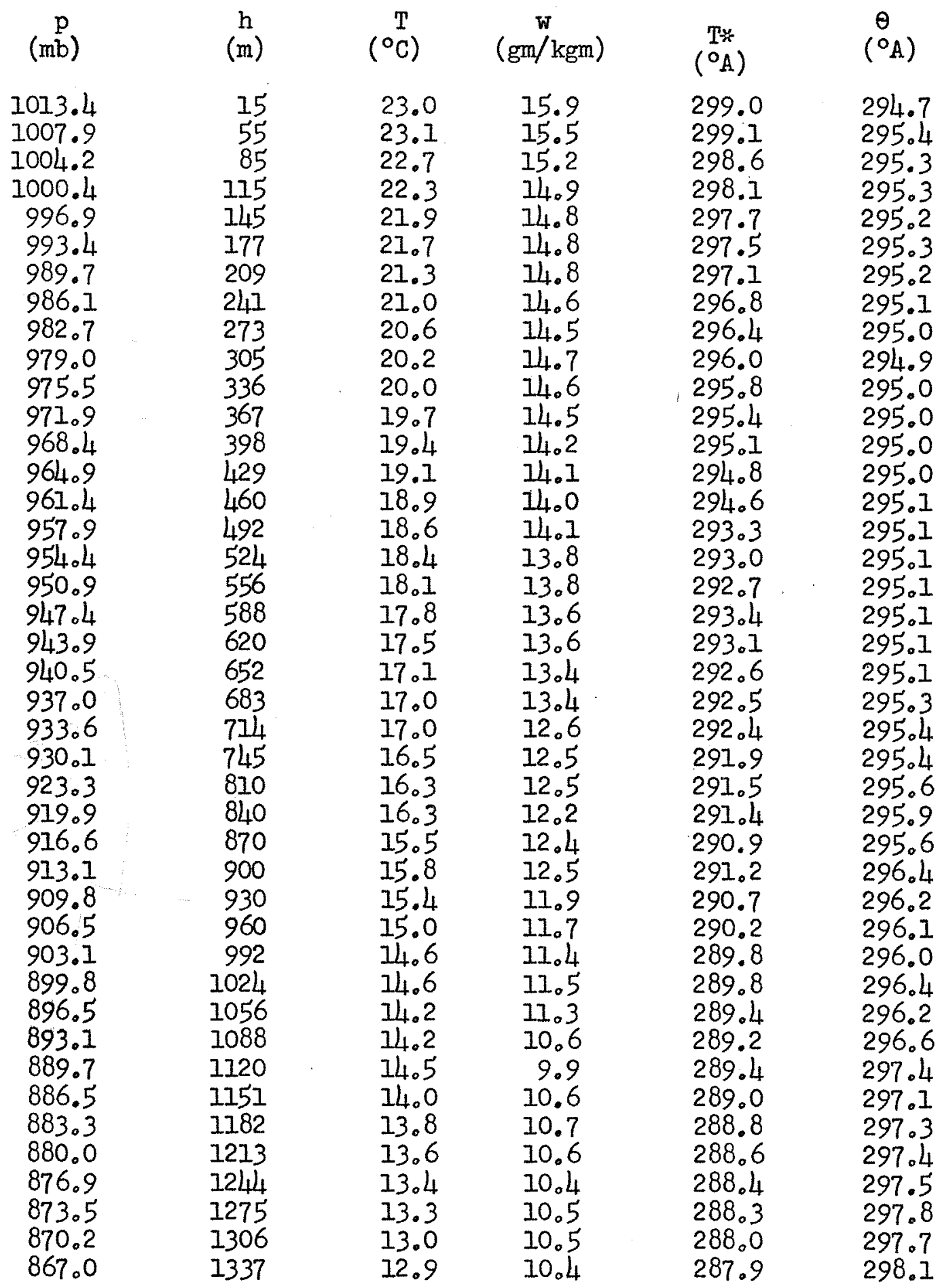


March 18, 1953. 1450 LST (contd.)

$\begin{array}{cccccc}\begin{array}{c}\mathrm{p} \\ (\mathrm{mb})\end{array} & \begin{array}{c}\mathrm{h} \\ (\mathrm{m})\end{array} & \begin{array}{c}\mathrm{T} \\ \left({ }^{\circ} \mathrm{C}\right)\end{array} & \begin{array}{c}\mathrm{w} \\ (\mathrm{gm} / \mathrm{kgm})\end{array} & \begin{array}{c}\mathrm{T*} \\ \left({ }^{\circ} \mathrm{A}\right)\end{array} & \begin{array}{c}\theta \\ \left({ }^{\circ} \mathrm{A}\right)\end{array} \\ 863.7 & 1368 & 12.6 & 10.2 & 287.6 & 298.1 \\ 860.5 & 1399 & 12.5 & 10.2 & 287.5 & 298.3 \\ 857.4 & 1430 & 12.3 & 9.8 & 287.2 & 298.4 \\ 854.1 & 1160 & 12.1 & 9.5 & 286.9 & 298.5 \\ 850.9 & 1485 & 11.9 & 9.7 & 286.8 & 298.6 \\ 847.8 & 1511 & 11.7 & 9.6 & 286.5 & 298.8 \\ 844.5 & 1537 & 11.7 & 9.4 & 286.5 & 299.1 \\ 847.2 & 1563 & 11.8 & 8.5 & 286.5 & 299.6 \\ 838.3 & 1589 & 11.7 & 9.0 & 286.4 & 299.7 \\ 835.1 & 1615 & 11.0 & 9.6 & 285.8 & 299.4 \\ 832.0 & 1645 & 11.3 & 8.5 & 286.0 & 300.0 \\ 828.9 & 1675 & 11.7 & 8.0 & 286.3 & 300.6 \\ 825.8 & 1715 & 11.3 & 8.0 & 285.9 & 300.6 \\ 822.7 & 1745 & 11.3 & 8.0 & 285.9 & 300.9 \\ 813.5 & 1835 & 10.8 & 8.0 & 285.2 & 301.2 \\ 810.4 & 1865 & 10.9 & 6.0 & 285.1 & 301.5 \\ 807.3 & 1895 & 11.1 & 5.0 & 285.2 & 302.1 \\ 798.2 & 2005 & 11.3 & 4.0 & 285.2 & 303.3\end{array}$


March 21, 1953. 1400 LST. Sounding in cloudy area.

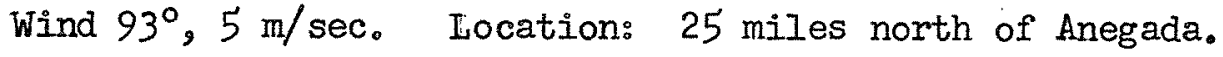

\begin{tabular}{|c|c|c|c|c|c|}
\hline $\begin{array}{c}\mathrm{p} \\
(\mathrm{mb})\end{array}$ & $\begin{array}{c}\mathrm{h} \\
(\mathrm{m})\end{array}$ & $\left({ }^{\mathrm{T}} \mathrm{C}\right)$ & $(\mathrm{gm} / \mathrm{kgm})$ & $\stackrel{\mathrm{T} *}{\left({ }^{\circ} \mathrm{A}\right)}$ & $\stackrel{\ominus}{\left({ }^{\circ} A\right)}$ \\
\hline 1015.8 & 20 & 25.8 & M & M & 297.4 \\
\hline 1013.9 & $35^{\circ}$ & 25.6 & M & M & 297.4 \\
\hline 1010.3 & 70 & 25.4 & M & M & 297.5 \\
\hline 1006.6 & 100 & 25.1 & M & M & 297.5 \\
\hline 1002.9 & 135 & 24.7 .7 & M & M & 297.5 \\
\hline 999.3 & 166 & 24.6 & M & M & 297.7 \\
\hline 995.8 & 197 & 23.9 & M & M & 297.3 \\
\hline 991.1 & 228 & 23.8 & M & M & 297.6 \\
\hline 988.5 & 259 & 23.4 & 16.8 & 299.6 & 297.4 \\
\hline 985.0 & 290 & 23.2 & 16.8 & 299.4 & 297.5 \\
\hline 981.4 & 322 & 23.1 & 16.1 & 299.2 & 297.7 \\
\hline 974.3 & 386 & 22.6 & 17.1 & 298.9 & 297.8 \\
\hline 970.8 & 417 & 22.2 & 17.0 & 298.5 & 297.7 \\
\hline 967.3 & 448 & 22.1 & 17.0 & 298.4 & 298.0 \\
\hline 963.8 & 480 & 21.9 & 16.4 & 298.1 & 298.0 \\
\hline 960.3 & 510 & 21.9 & 16.8 & 298.1 & 298.4 \\
\hline 956.8 & 540 & 22.0 & 16.4 & 298.2 & 298.9 \\
\hline 954.3 & 570 & 21.3 & 16.1 & 297.3 & 298.4 \\
\hline 949.8 & 600 & 21.2 & 16.3 & 297.3 & 298.7 \\
\hline 946.3 & 630 & 20.8 & 15.8 & 296.8 & 298.7 \\
\hline 942.9 & 660 & 20.7 & 15.8 & 296.7 & 299.0 \\
\hline 936.0 & 720 & 18.4 & 10.9 & 293.5 & 297.1 \\
\hline 929.1 & 780 & 18.4 & 9.3 & 293.3 & 297.9 \\
\hline 925.7 & 808 & 18.4 & 9.4 & 293.3 & 298.2 \\
\hline 922.3 & 836 & 18.1 & 9.5 & 293.0 & 298.3 \\
\hline 919.0 & 864 & 17.8 & 9.7 & 292.7 & 298.2 \\
\hline 915.5 & 892 & 17.4 & 10.2 & 292.4 & 298.0 \\
\hline 912.2 & 920 & 17.2 & 10.2 & 292.2 & 298.2 \\
\hline 905.5 & 976 & 16.7 & 10.4 & 291.7 & 298.3 \\
\hline 902.2 & 1004 & 16.6 & 10.1 & 291.6 & 298.5 \\
\hline 898.9 & 1032 & 16.4 & 9.7 & 291.3 & 298.7 \\
\hline 895.5 & 1060 & 16.1 & 9.6 & 291.0 & 298.6 \\
\hline 892.1 & 1095 & 15.6 & 10.8 & 290.7 & 298.5 \\
\hline 888.9 & 1130 & 15.2 & 11.1 & 290.4 & 298.4 \\
\hline 885.7 & 1165 & 15.1 & 11.0 & 290.2 & 298.6 \\
\hline 882.4 & 1200 & 15.1 & 1100 & 290.2 & 299.0 \\
\hline 879.3 & 1235 & 14.9 & 11.0 & 290.0 & 299.0 \\
\hline 872.6 & 1305 & 14.6 & 10.4 & 289.6 & 299.4 \\
\hline 869.4 & 1340 & 14.5 & 9.9 & 289.4 & 299.6 \\
\hline 866.1 & 1375 & 14.5 & 9.1 & 289.3 & 299.8 \\
\hline 862.9 & 14,10 & 14.5 & 8.9 & 289.3 & 300.0 \\
\hline 859.8 & 1444 & 14.1 & 9.7 & 289.0 & 300.0 \\
\hline 856.5 & 1478 & 13.8 & 9.5 & 288.7 & 300.0 \\
\hline 853.3 & 151.2 & 13.9 & 8.2 & 288.5 & 300.5 \\
\hline 850.2 & 1556 & 14.0 & 7.1 & 288.5 & 300.8 \\
\hline 846.9 & 1580 & 13.9 & 7.3 & 288.4 & 301.2 \\
\hline $8 L$ & 1642 & 13.8 & 6.2 & 288.1 & 301.6 \\
\hline 837 & 1673 & 13.6 & 5.5 & 287.8 & 301.7 \\
\hline
\end{tabular}


March 21, 1953. 1400 IST. (contdo)

$\begin{array}{cccccc}\begin{array}{c}\mathrm{p} \\ (\mathrm{mb})\end{array} & \begin{array}{c}\mathrm{h} \\ (\mathrm{m})\end{array} & \begin{array}{c}\mathrm{T} \\ \left({ }^{\circ} \mathrm{C}\right)\end{array} & \begin{array}{c}\mathrm{W} \\ (\mathrm{gm} / \mathrm{kgm})\end{array} & \begin{array}{c}\mathrm{T} * \\ \left({ }^{\circ} \mathrm{A}\right)\end{array} & \begin{array}{c}\Theta \\ \left({ }^{\circ} \mathrm{A}\right)\end{array} \\ 834.4 & 1704 & 13.5 & 5.2 & 287.6 & 302.0 \\ 831.3 & 1735 & 13.4 & 5.2 & 287.5 & 302.3 \\ 828.2 & 1766 & 13.1 & 5.8 & 287.3 & 302.3 \\ 825.1 & 1797 & 12.6 & 6.7 & 287.0 & 302.0 \\ 822.0 & 1828 & 12.7 & 5.7 & 286.9 & 302.5 \\ 818.9 & 1859 & 12.4 & 6.3 & 286.7 & 302.5 \\ 815.9 & 1890 & 12.0 & 7.1 & 286.4 & 302.5\end{array}$


March 25, 1953. III5 IST. Sounding in cloudy area。

Wind $89^{\circ}, 10 \mathrm{~m} / \mathrm{sec}$. Location: 2 miles north of Anegada.

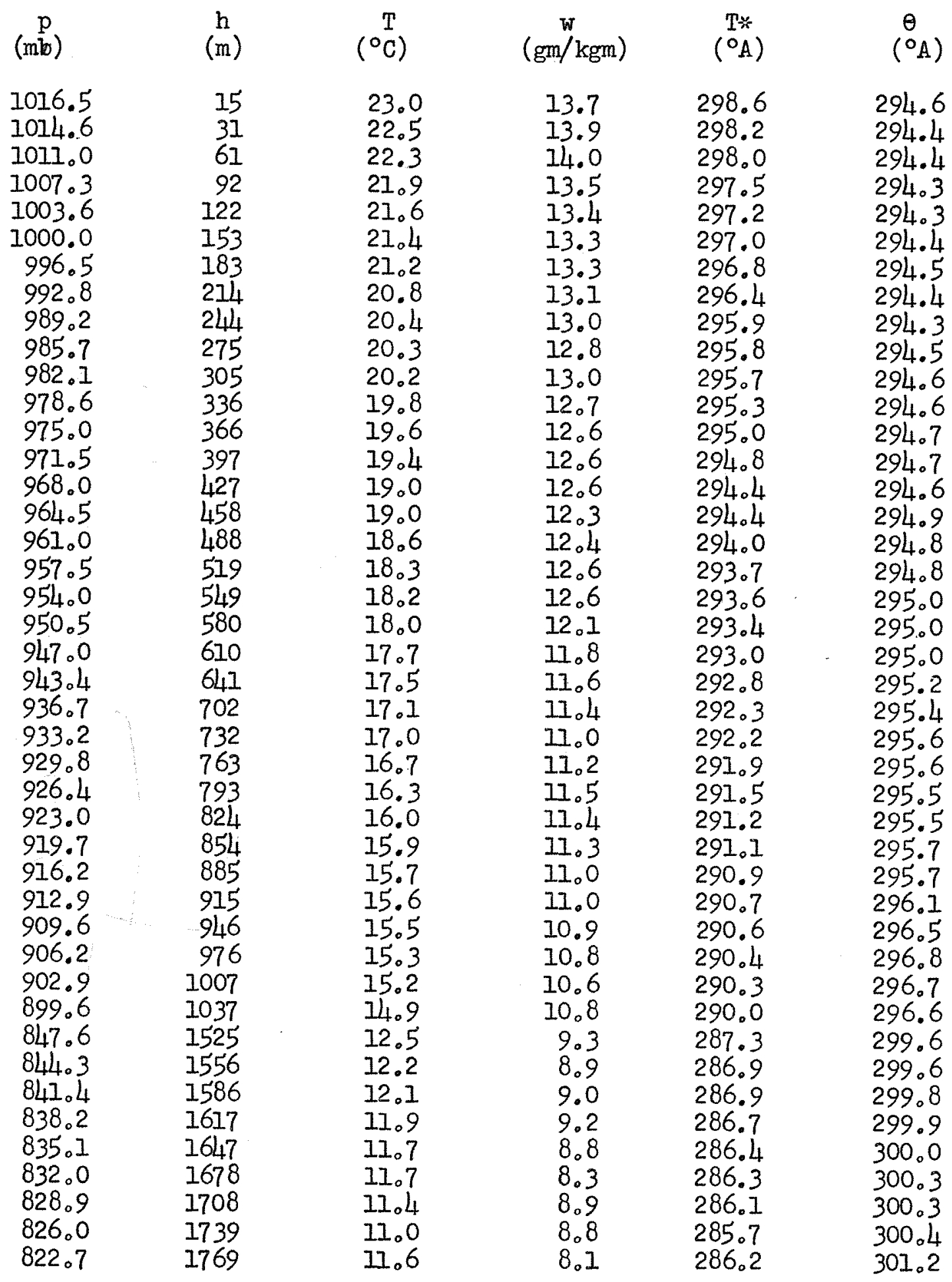


March 25, 1953。 1115 LST。 (contdo)

\begin{tabular}{|c|c|c|c|c|c|}
\hline $\begin{array}{c}\mathrm{p} \\
(\mathrm{mb})\end{array}$ & $\stackrel{\mathrm{h}}{(\mathrm{m})}$ & $\left({ }^{\circ} \mathrm{T}\right)$ & $(\mathrm{gm} / \mathrm{kgm})$ & $\left({ }^{\mathrm{T}} \mathrm{A}\right)$ & $\left.\stackrel{\ominus}{\left({ }^{\circ}\right.}\right)$ \\
\hline $\begin{array}{l}819.6 \\
816.6 \\
810.4 \\
807.4 \\
804.3 \\
801.3 \\
798.3 \\
795.3 \\
792.2 \\
789.3 \\
787.8 \\
786.3 \\
783.6 \\
782.1 \\
780.7\end{array}$ & $\begin{array}{l}1800 \\
1830 \\
1891 \\
1922 \\
1952 \\
1983 \\
2013 \\
2044 \\
2074 \\
2105 \\
2120 \\
2135 \\
2166 \\
2181 \\
2196\end{array}$ & $\begin{array}{r}11.1 \\
11.0 \\
10.8 \\
10.6 \\
10.6 \\
10.6 \\
10.8 \\
10.6 \\
10.0 \\
10.3 \\
10.4 \\
10.3 \\
10.0 \\
9.9 \\
9.7\end{array}$ & $\begin{array}{l}7.8 \\
7.6 \\
7.4 \\
7.3 \\
7.3 \\
7.3 \\
7.4 \\
7.6 \\
7.8 \\
4.9 \\
5.3 \\
5.5 \\
5.4 \\
6.1 \\
6.3\end{array}$ & $\begin{array}{l}285.0 \\
285.5 \\
285.5 \\
285.0 \\
282.5 \\
282.5 \\
282.5 \\
282.5 \\
281.5 \\
282.6 \\
282.0 \\
282.5 \\
282.5 \\
282.0 \\
281.8\end{array}$ & $\begin{array}{l}301.0 \\
301.1 \\
301.4 \\
301.6 \\
301.9 \\
302.3 \\
302.7 \\
302.9 \\
302.6 \\
303.4 \\
303.6 \\
303.6 \\
303.6 \\
303.6 \\
303.6\end{array}$ \\
\hline
\end{tabular}


Masch $30,1953.1112$ IST. Sounding in clear area near edge of cloudy area. High cirrus present。 Wind $110^{\circ}, 5 \mathrm{~m} / \mathrm{sec}$. Location: 12 miles eastosoutheast. of Anegada.

\begin{tabular}{|c|c|c|c|c|c|}
\hline$\underset{(m b)}{p}$ & $\stackrel{h}{(m)}$ & $\left({ }^{\circ} \mathrm{C}\right)$ & $(\mathrm{gm} / \mathrm{kgm})$ & $\stackrel{\mathrm{T} *}{\left({ }^{\circ} \mathrm{A}\right)}$ & $\stackrel{\theta}{\left({ }^{\circ} \mathrm{A}\right)}$ \\
\hline 1012.9 & 34 & 25.2 & 16.6 & 301.4 & 297.1 \\
\hline 1009.3 & 66 & 24.9 & 16.8 & 301.2 & 297.4 \\
\hline 1005.6 & 96 & 24.4 & 17.0 & 300.7 & 297.0 \\
\hline 1001.9 & 129 & 24.2 & 16.7 & 300.4 & 297.1 \\
\hline 998.3 & 160 & 24.0 & 16.6 & 300.2 & 297.4 \\
\hline 994.8 & 192 & 23.6 & 16.8 & 299.8 & 297.2 \\
\hline 991.1 & 224 & 23.2 & 16.5 & 299.4 & 297.0 \\
\hline 987.5 & 256 & 23.0 & $16 . \overline{4}$ & 299.2 & 297.2 \\
\hline 984.0 & 288 & 22.8 & 16.0 & 298.9 & 297.3 \\
\hline 980.4 & 320 & 22.5 & 16.1 & 298.6 & 297.4 \\
\hline 976.7 & 351 & 22.3 & 15.9 & 298.4 & 297.4 \\
\hline 973.3 & 382 & 21.9 & 16.0 & 298.0 & 297.3 \\
\hline 969.8 & 413 & 21.7 & 15.5 & 297.7 & 297.4 \\
\hline 966.3 & $44 \sqrt{4}$ & 21.5 & 15.1 & 297.4 & 297.4 \\
\hline 962.8 & 475 & 21.2 & 15.1 & 297.1 & 297.4 \\
\hline 955.8 & 540 & 20.7 & 15.0 & 296.6 & 297.5 \\
\hline 952.3 & 570 & 20.4 & 14.2 & 296.2 & 297.4 \\
\hline 948.8 & 600 & 20.1 & 14.4 & 295.9 & 297.4 \\
\hline 945.3 & 633 & 20.0 & 14,2 & 295.7 & 297.6 \\
\hline 941.9 & 666 & 19.8 & 13.9 & 295.5 & 297.8 \\
\hline 938.4 & 699 & 19.6 & 14.0 & 295.3 & 298.0 \\
\hline 935.0 & 732 & 19.3 & 13.4 & 294.9 & 298.0 \\
\hline 931.5 & 765 & 19.2 & 13.4 & 294.8 & 298.2 \\
\hline 928.1 & 795 & 79.2 & 13.1 & 294.8 & 298.5 \\
\hline 924.7 & 825 & 19.2 & 12.6 & 294.6 & 298.9 \\
\hline 921.3 & 857 & 18.9 & 12.5 & 294.3 & 299.0 \\
\hline 914.5 & 920 & $18.5^{\circ}$ & 12.3 & 293.9 & 299.3 \\
\hline 911.2 & 950 & 18.5 & 12.3 & 293.9 & 299.6 \\
\hline 907.9 & 980 & 18.1 & 12.4 & 293.5 & 299.5 \\
\hline 904.5 & 1010 & 17.8 & 12.5 & 293.2 & 299.5 \\
\hline 901.2 & 1040 & 17.5 & 12.2 & 292.9 & 299.5 \\
\hline 897.9 & 1072 & 17.3 & 12.3 & 292.7 & 299.5 \\
\hline 894.5 & 1104 & 17.1 & 12.4 & 292.5 & 299.6 \\
\hline 891.1 & 1136 & 17.0 & 12.2 & 292.4 & $300_{0} 1$ \\
\hline 887.9 & 1168 & 16.9 & 11.6 & 292.2 & 300.1 \\
\hline 884.7 & 1200 & 16.7 & 11.5 & 291.9 & 300.3 \\
\hline 881.4 & 1232 & 16.1 & 11.4 & 291.3 & 300.1 \\
\hline 878.3 & 1260 & 16.1 & 11.5 & 291.3 & 300.4 \\
\hline 871,6 & 1325 & 15.8 & 11.6 & 291.0 & 300.7 \\
\hline 868.4 & 1355 & 25.3 & 11.8 & 290.6 & 300.5 \\
\hline 865.1 & 1386 & 15.0 & 21.5 & 290.2 & 300.5 \\
\hline 861.9 & 1417 & 25.0 & $11 \cdot 4$ & 290.2 & 300.8 \\
\hline 858.8 & 1448 & 14.8 & 11.5 & 290.0 & 300.9 \\
\hline 855.5 & 1479 & 24.6 & 12.4 & 289.8 & 301.0 \\
\hline 852.3 & 1510 & 14.6 & 21.1 & 289.8 & 301.4 \\
\hline 845.9 & 1561 & 1404 & 10.8 & 289.5 & 301.7 \\
\hline
\end{tabular}


ApriI 1, 1953. 1045 IST. Sounding in clear area near cloudy area. Some cirrus present. Wind $146^{\circ}, 4 \mathrm{~m} / \mathrm{sec}$. Location: 10 miles east of Anegada.

\begin{tabular}{|c|c|c|c|c|c|}
\hline$\left(\begin{array}{c}p \\
(m b\end{array}\right)$ & $\frac{h}{(m)}$ & $\left(\begin{array}{c}\mathrm{T} \\
\left({ }^{\circ} \mathrm{C}\right)\end{array}\right.$ & $(\mathrm{gm} / \mathrm{kgm})$ & $\begin{array}{c}\mathrm{T} \text { 辛 } \\
\left({ }^{\circ} \mathrm{A}\right)\end{array}$ & $\stackrel{\theta}{\left({ }^{\circ} \mathrm{A}\right)}$ \\
\hline 1014.8 & 15 & 24.9 & 15.6 & 300.9 & 296.7 \\
\hline 1012.9 & 30 & 24.6 & 15.4 & 300.6 & 296.6 \\
\hline 1009.3 & 65 & 25.0 & 15.3 & 300.9 & 297.4 \\
\hline 1005.6 & 97 & 24.3 & 15.5 & 300.3 & 297.0 \\
\hline 1001.9 & 128 & 24.1 & 15.2 & 300.0 & 297.1 \\
\hline 998.3 & 160 & 23.7 & 15.3 & 299.6 & 297.2 \\
\hline $994_{0} 8$ & 192 & 23.5 & 15.4 & 299.4 & 297.0 \\
\hline 991.1 & 224 & 23.2 & 15.5 & 299.1 & 297.1 \\
\hline 987.5 & 256 & 22.9 & 15.0 & 298.8 & 297.1 \\
\hline 984.0 & 288 & 22.7 & 15.5 & 298.6 & 297.4 \\
\hline 980.4 & 320 & 22.2 & 15.1 & 298.1 & 297.0 \\
\hline 976.9 & 350 & 21.9 & 14.2 & 297.6 & 297.0 \\
\hline 973.3 & 382 & 21.6 & 14.3 & 297.3 & 297.0 \\
\hline 962.8 & 475 & 20.6 & 13.0 & 296.1 & 296.8 \\
\hline 959.3 & 506 & 20.4 & 12.7 & 295.8 & 296.9 \\
\hline 955.8 & 537 & 20.2 & 12.7 & 295.6 & 297.0 \\
\hline 952.3 & 568 & 20.2 & 12.6 & 295.6 & 297.4 \\
\hline 948.8 & 599 & 19.7 & 12.7 & 295.1 & 297.0 \\
\hline 945.3 & 630 & 19.5 & 12.5 & 294.9 & 297.1 \\
\hline 938.4 & 695 & 19.1 & 12.7 & 294.5 & 297.4 \\
\hline 935.0 & 726 & 18.5 & 12.5 & 293.9 & 297.2 \\
\hline 931.5 & 757 & 18.6 & 11.9 & 293.9 & 297.6 \\
\hline 928.1 & 788 & 18.5 & 11.9 & 293.8 & 297.9 \\
\hline 924.7 & 819 & 18.4 & 12.1 & 293.7 & 298.1 \\
\hline 921.3 & 850 & 18.0 & 12.1 & 293.3 & 298.1 \\
\hline 918.0 & 880 & 17.8 & 12.1 & 293.1 & 298.2 \\
\hline 914.5 & 913 & 17.8 & 11.5 & 293.0 & 298.5 \\
\hline 911.2 & 944 & 17.9 & 11.1 & 293.1 & 299.1 \\
\hline 904.5 & 1004 & 17.4 & 10.9 & 292.5 & 299.2 \\
\hline 901.2 & 1034 & 17.2 & 10.8 & 292.3 & 299.3 \\
\hline 897.9 & 1064 & 17.1 & 10.6 & 292.1 & 299.4 \\
\hline 894.5 & 1095 & 16.6 & 10.7 & 291.6 & 299.2 \\
\hline 878.3 & 1255 & 16.0 & 8.4 & 290.7 & 300.2 \\
\hline 874.9 & 1287 & 15.8 & 8.4 & 290.5 & 300.4 \\
\hline 871.6 & 1319 & 15.7 & 8.5 & $290 . \overline{4}$ & 300.6 \\
\hline 868.4 & 1351 & 15.2 & 8.4 & 289.5 & 300.4 \\
\hline 865.1 & 1383 & 15.1 & 7.9 & 289.7 & 300.6 \\
\hline 861.9 & 1415 & 15.0 & 7.7 & 289.5 & 300.8 \\
\hline 858.8 & 1444 & 15.0 & 7.5 & 289.5 & 301.1 \\
\hline 855.5 & 1473 & 14.9 & 6.9 & 289.3 & 301.3 \\
\hline 852.3 & 1500 & 14.7 & 6.8 & 289.1 & 301.5 \\
\hline 849.2 & 1525 & 14.6 & 6.5 & 288.9 & 301.5 \\
\hline 8450. & 1550 & 14.6 & 6.3 & 288.9 & 302.0 \\
\hline
\end{tabular}


April 2, 1953. 1445 IST. Sounding in clear area north of small cloudy area. Some cirrus present. Wind $120^{\circ}, 4 \mathrm{~m} / \mathrm{sec}$.

Location: 5 miles east of Anegada.

\begin{tabular}{|c|c|c|c|c|c|}
\hline $\begin{array}{c}p \\
(m b)\end{array}$ & $\stackrel{\mathrm{h}}{(\mathrm{m})}$ & $\left(\begin{array}{c}\mathrm{T} \\
\left({ }^{\circ} \mathrm{C}\right)\end{array}\right.$ & $\left(\begin{array}{c}\mathrm{w} \\
(\mathrm{gm} / \mathrm{kgm})\end{array}\right.$ & $\begin{array}{c}T^{*} \\
\left({ }^{\circ} A\right)\end{array}$ & $\stackrel{\theta}{\left({ }^{\circ} \mathrm{A}\right)}$ \\
\hline 1011.2 & 35 & 25.3 & 14.9 & 301.2 & 297.4 \\
\hline 1007.6 & 62 & 25.2 & 14.3 & 301.0 & 297.6 \\
\hline 1003.9 & 95 & 24.9 & 14.7 & 300.8 & 297.7 \\
\hline 1000.2 & 130 & 24.4 & 14.6 & 300.2 & 297.4 \\
\hline 996.6 & 155 & 24.3 & 14.8 & 300.1 & 297.6 \\
\hline 989.4 & 218 & 23.5 & 14.6 & 299.3 & 297.4 \\
\hline 985.8 & 254 & 23.1 & 14.5 & 298.9 & 297.4 \\
\hline 982.3 & 290 & 22.9 & 14.7 & 298.7 & 297.4 \\
\hline 978.7 & 320 & 22.4 & 14.4 & 298.2 & 297.2 \\
\hline 975.2 & 350 & 22.1 & 14.5 & 297.9 & 297.1 \\
\hline 971.6 & 380 & 21.6 & 14.3 & 297.4 & 296.9 \\
\hline 968.1 & 418 & 21.4 & 14.3 & 297.2 & 296.9 \\
\hline 964.6 & 445 & 21.1 & 14.5 & 296.9 & 296.9 \\
\hline 961.1 & 480 & 20.9 & 14.2 & 296.6 & 297.1 \\
\hline 957.6 & 507 & 20.5 & 14.5 & 296.3 & 296.9 \\
\hline 954.1 & 544 & 20.4 & 14.3 & 296.2 & 297.1 \\
\hline 950.6 & 570 & 20.0 & 14.1 & 295.7 & 297.0 \\
\hline 943.6 & 632 & 19.9 & 12.6 & 295.3 & 297.6 \\
\hline 940.2 & 668 & 19.9 & 11.4 & 295.1 & 298.0 \\
\hline 936.7 & 700 & 19.8 & 11.0 & 295.0 & 298.3 \\
\hline 933.3 & 735 & 19.6 & 10.9 & 294.7 & 298.4 \\
\hline 929.8 & 760 & 19.3 & 10.7 & 294.4 & 298.5 \\
\hline 926.4 & 795 & 19.0 & 10.8 & 294.1 & 298.5 \\
\hline 923.0 & 825 & 18.9 & 10.2 & 293.9 & 298.7 \\
\hline 919.6 & $855^{\circ}$ & 18.9 & 9.6 & 293.8 & 299.1 \\
\hline 916.3 & 890 & 18.9 & 9.4 & 293.8 & 299.4 \\
\hline 912.8 & 915 & 18.8 & 9.3 & 293.7 & 299.6 \\
\hline 909.5 & $955^{\circ}$ & 18.8 & 9.4 & 293.7 & 299.9 \\
\hline 906.2 & 985 & 18.3 & 9.6 & 293.2 & 299.7 \\
\hline 902.8 & 1015 & 18.2 & 9.2 & 293.0 & 299.9 \\
\hline 899.5 & 1042 & 17.9 & 9.9 & 292.8 & 299.9 \\
\hline 896.2 & 1075 & 17.9 & 9.2 & 292.7 & 300.2 \\
\hline 892.8 & 1105 & 17.6 & 9.2 & 292.4 & 300.3 \\
\hline 889.4 & $111_{4} \mathrm{O}$ & 17.3 & 9.2 & 292.1 & 300.3 \\
\hline 886.2 & 1170 & 17.2 & 9.1 & 292.0 & 300.5 \\
\hline 883.0 & 1200 & 17.0 & 9.4 & 291.9 & 300.6 \\
\hline 879.7 & 1230 & 16.7 & 9.5 & 291.6 & 300.7 \\
\hline 876.6 & 1260 & 16.4 & 9.5 & 291.3 & 300.6 \\
\hline 873.2 & 1295 & 16.3 & 9.7 & 291.2 & 300.9 \\
\hline 869.9 & 1325 & 16.2 & 9.4 & 290.9 & 300.9 \\
\hline 866.7 & 1355 & 15.6 & 9.3 & 290.4 & 300.8 \\
\hline & 1390 & 15.5 & 8.8 & 290.2 & 301.1 \\
\hline 860.2 & 1420 & 15.1 & 8.8 & 289.8 & 301.0 \\
\hline & 1456 & 15.1 & 7.5 & 289.6 & 301.3 \\
\hline 85 & 1485 & 15.2 & 7.3 & 289.7 & 301.7 \\
\hline 850 & 1520 & 15.2 & & 289.9 & 302.0 \\
\hline
\end{tabular}


Apri工 2, 1953. 1445 LST. (contd.)

$\underset{(m b)}{p}$

847.5

844.2

838.0

834.8

831.7

828.6

825.5

822.4

819.3

813.2

840.9

838.0

834.8

831.7

828.6

825.5

822.4

818.3

816.2

813.2

807.0

804.0

800.9

797.9

794.9

791.9

788.8

785.9

782.9

780.1

777.3

774.5

771.6

768.7

765.7

760.0

754.0 h

1553

1580

1680

1713

1745

1780

1810

1840

1900

1622

1650

1680

1713

1745

1780

1810

1840

1870

1900

1968

2000

2033

2065

2098

2130

2162

2194

2226

2258

2290

2318

2339

2360

2388

2437

2483

$$
\left({ }^{\circ} \mathrm{C}\right)
$$

14.9

14.5

14.2

14.6

114.7

14.5

14.2

工4. 0

13.8

12.7

II.I

14.1

14.2

14.0

13.8

13.6

13.5

13.5

13.5

13.0

$12 . ?$

11.8

11.9

11.6

11.6

11.5

11.5

II. 2

11.2

II. 0

11.0

10.7

10.5

10.3

10.3

9.7

9.2 $\begin{array}{ccc}\mathrm{w} & \mathrm{T} * & \theta \\ (\mathrm{gm} / \mathrm{kgm}) & \left({ }^{\mathrm{O}} \mathrm{A}\right) & \left({ }^{\circ} \mathrm{A}\right)\end{array}$

$8.6 \quad 289.6$

$9.0 \quad 289.3$

$9.3 \quad 289.0$

$5.2 \quad 288.7$

$4.9 \quad 288.8$

$4.5 \quad 288.5$

3.9288 .1

$3.7 \quad 287.9$

3.6

7.6

9.8

9.6

8.9

8.6

8.4

8.3

7.8

6.6

6.0

7.2

7.4

7.5

6.4

6.7

6.6

5.6

5.8

5.6

5.0

4.4

3.9

4.0

3.9

4.3

3.7

3.5

3.7
287.6

287.2

289.0

289.0

289.0

288.7

288.5

288.2

288.1

287.8

287.7

287.5

287.4

286.3

286.4

286.0

286.0

285.7

285.7

285.4

285.3

285.0

285.1

284.6

284.4

284.3

284.1

283.5

283.0
302.0

301.9

302.2

303.0

303.5

303.6

303.6

303.7

303.8

303.3

301.9

302.2

302.6

302.7

302.8

303.0

303.2

303.5

303.7

303.6

303.9

303.3

303.7

303.7

304.0

304.3

304.5

304.5

304.7

304.9

305.2

305.3

305.4

305.5

305.8

305.7

305.8 
April 4, 1953。 1150 LST. Sounding in clear area. No clouds except over islands. Wind $140^{\circ}, 6 \mathrm{~m} / \mathrm{sec}$. Location: 5 miles east of Anegada.

\begin{tabular}{|c|c|c|c|c|c|}
\hline$\underset{(m b)}{p}$ & $\begin{array}{c}\mathrm{h} \\
(\mathrm{m})\end{array}$ & $\left({ }^{\mathrm{T}} \mathrm{C}\right)$ & $\begin{array}{c}\text { W } \\
(\mathrm{gm} / \mathrm{kgm})\end{array}$ & $\left({ }^{\mathrm{T} *} \mathrm{~A}\right)$ & $\stackrel{\ominus}{\left({ }^{\circ} \mathrm{A}\right)}$ \\
\hline 1014.4 & 23 & 26.2 & 15.0 & 302.1 & 298.0 \\
\hline 1009.6 & 65 & 25.4 & 14.6 & 301.3 & 297.6 \\
\hline 1005.9 & 100 & 25.0 & 14.4 & 300.8 & 297.6 \\
\hline 1002.2 & 130 & 24.6 & 14.1 & 300.4 & 297.5 \\
\hline 998.6 & 163 & 24.3 & 14.3 & 300.1 & 297.5 \\
\hline 995.1 & 195 & 24.1 & 14.3 & 299.9 & 297.6 \\
\hline 991.4 & 228 & 23.8 & $14 . \overline{4}$ & 299.6 & 297.6 \\
\hline 987.8 & 259 & 23.4 & 14.6 & 299.2 & 297.5 \\
\hline 984.3 & 290 & 23.0 & 714.4 & 298.8 & 297.4 \\
\hline 980.7 & 322 & 22.7 & 14.2 & 298.5 & 297.5 \\
\hline 977.2 & 354 & 22.6 & 14.1 & 298.4 & 297.6 \\
\hline 973.6 & 385 & 22.2 & 14.3 & 298.0 & 297.5 \\
\hline 970.1 & 417 & 22.0 & 14.2 & 297.8 & 297.5 \\
\hline 966.6 & 449 & 21.9 & I4.0 & 297.6 & 297.8 \\
\hline 963.1 & 479 & 21.5 & 14.3 & 297.3 & 297.6 \\
\hline 959.6 & 511 & 21.2 & 14.1 & 296.9 & 297.6 \\
\hline 956.0 & $5 \longdiv { 4 3 }$ & 21.0 & $I_{4.0}$ & 296.7 & 297.7 \\
\hline 952.6 & 575 & 20.8 & 13.8 & 296.5 & 297.8 \\
\hline 949.1 & 607 & 20.4 & $1 \longdiv { 4 . 1 }$ & 296.1 & 297.6 \\
\hline 945.6 & 639 & 20.0 & 14.1 & 295.7 & 297.5 \\
\hline 942.2 & 669 & 19.8 & 13.7 & 295.4 & 297.7 \\
\hline 938.7 & 699 & 19.8 & 13.8 & 295.5 & 298.1 \\
\hline 935.3 & 729 & 19.8 & 12.2 & 295.2 & 298.5 \\
\hline 931.8 & 759 & 19.7 & 11.6 & 295.0 & 298.7 \\
\hline 928.4 & 790 & 19.6 & 10.4 & 294.7 & 298.9 \\
\hline 925.0 & 822 & 19.4 & 10.2 & 294.4 & 299.0 \\
\hline 921.6 & 854 & 18.9 & 10.8 & 294.0 & 298.9 \\
\hline 918.3 & 886 & 18.9 & 10.1 & 293.9 & 299.2 \\
\hline 914.8 & 918 & 18.7 & 10.1 & 293.7 & 299.4 \\
\hline 911.5 & 950 & 18.8 & 9.6 & 293.7 & 299.8 \\
\hline 908.2 & 980 & 18.5 & 9.7 & 293.4 & 299.7 \\
\hline 904.8 & 1014 & 18.2 & 9.6 & 293.1 & 299.8 \\
\hline 898.2 & 1075 & 17.5 & 9.9 & 292.4 & 299.6 \\
\hline 894.8 & 1107 & 17.4 & 9.9 & 292.3 & 299.9 \\
\hline 891.4 & 1740 & 17.0 & 10.1 & 292.0 & 299.9 \\
\hline 888.2 & 1170 & 16.8 & 9.9 & 291.7 & 299.9 \\
\hline 885.0 & 1202 & 16.7 & 9.2 & 291.5 & 300.1 \\
\hline 868.7 & 1360 & 15.2 & 9.1 & 290.0 & 300.2 \\
\hline 865.4 & 1390 & 14.8 & 10.1 & 289.8 & 300.2 \\
\hline 862.2 & $\sqrt{4} 23$ & 14.6 & 10.2 & 289.6 & 300.2 \\
\hline 859.1 & 1457 & 14.6 & 10.2 & 289.6 & 300.6 \\
\hline 855.8 & 1490 & 14.6 & 8.1 & 289.2 & 301.0 \\
\hline 852.6 & 1523 & 14.2 & 8.5 & 288.9 & 300.8 \\
\hline 849.5 & 1556 & 14.I & 8.3 & 288.8 & 301.4 \\
\hline 846.2 & 1580 & 13.9 & 7.5 & 288.4 & 301.1 \\
\hline 842.9 & 1615 & 13.9 & 7.3 & 288.4 & 301.4 \\
\hline 840.0 & 1642 & 13.7 & 7.3 & 288.2 & 301.5 \\
\hline 836.8 & 1674 & 13.6 & 7.3 & 288.1 & 301.8 \\
\hline
\end{tabular}


ApriI 4, 1953. 1150 IST. (contd.)

$\begin{array}{ccc}\begin{array}{c}\mathrm{p} \\ (\mathrm{mb})\end{array} & \begin{array}{c}\mathrm{h} \\ (\mathrm{m})\end{array} & \begin{array}{c}\mathrm{T} \\ \left({ }^{\circ} \mathrm{C}\right)\end{array} \\ 827.5 & 1767 & 13.3 \\ 824.4 & 1799 & 13.4 \\ 821.4 & 1830 & 13.6 \\ 818.2 & 1860 & 13.6 \\ 815.2 & 1890 & 13.6 \\ 813.6 & 1907 & 13.6 \\ 812.1 & 1920 & 13.8 \\ 809.0 & 1945 & 14.0 \\ 806.0 & 1972 & 13.9 \\ 802.9 & 1999 & 13.6 \\ 801.4 & 2009 & 13.7 \\ 799.9 & 2021 & 13.7 \\ 796.9 & 2047 & 13.7\end{array}$

$\begin{array}{ccc}\begin{array}{c}w \\ (\mathrm{gm} / \mathrm{kgm})\end{array} & \begin{array}{c}T * \\ \left.{ }^{\circ} \mathrm{A}\right)\end{array} & \begin{array}{c}\Theta \\ \left({ }^{\circ} \mathrm{A}\right)\end{array} \\ 6.7 & 287.7 & 302.6 \\ 5.5 & 287.6 & 302.9 \\ 5.3 & 287.7 & 303.4 \\ 5.7 & 287.8 & 303.6 \\ 5.8 & 287.8 & 304.0 \\ 6.4 & 287.9 & 304.2 \\ 5.7 & 288.0 & 304.5 \\ 4.9 & 288.1 & 304.9 \\ 4.7 & 287.9 & 305.1 \\ 4.8 & 287.6 & 305.2 \\ 5.0 & 287.8 & 305.5 \\ 4.8 & 287.7 & 305.7 \\ 4.4 & 287.7 & 306.0\end{array}$


April 5, 1953. 1300 LST. Sounding in clear area. . No cumulus present except over islands. Middle clouds $8 / 10$. Wind $140^{\circ}, 7.5 \mathrm{~m} / \mathrm{sec}$.

Location: 10 miles east of Anegada.

\begin{tabular}{|c|c|c|c|c|c|}
\hline$(\mathrm{mb})$ & $\underset{(m)}{h}$ & $\left(\begin{array}{c}\mathrm{T} \\
\left({ }^{\circ} \mathrm{C}\right)\end{array}\right.$ & $\begin{array}{c}\mathrm{w} \\
(\mathrm{gm} / \mathrm{kgm})\end{array}$ & $\stackrel{{ }^{\mathrm{T}} *}{\left.{ }^{\circ} \mathrm{A}\right)}$ & $\stackrel{\theta}{\left({ }^{\circ} \mathrm{A}\right.}$ \\
\hline 999.8 & 130 & 23.8 & 14.6 & 299.6 & 29 \\
\hline 996.2 & 160 & 23.4 & 14.3 & 299.2 & \\
\hline 992.7 & 190 & 23.4 & 13.4 & 299.0 & \\
\hline 989.0 & 225 & 23.3 & 13.2 & 298.9 & \\
\hline 985.4 & 257 & 23.1 & 13.6 & 298.8 & \\
\hline 981.9 & 290 & 22.8 & 13.7 & 298.5 & \\
\hline 978.3 & 320 & 22.4 & 13.4 & 298.0 & 297 \\
\hline 964.2 & 446 & 21.7 & 12.9 & 297.2 & \\
\hline 960.7 & 476 & 21.6 & 11.7 & 296.9 & \\
\hline 953.7 & 540 & 21.1 & 11.8 & 296.4 & 298 \\
\hline 950.2 & 570 & 20.6 & 11.8 & 295.9 & \\
\hline 946.7 & 600 & 20.5 & 17.9 & 295.8 & 298 \\
\hline 943.2 & 630 & 19.9 & 12.6 & 295.3 & \\
\hline 936.3 & 695 & 19.7 & 11.8 & 295.0 & \\
\hline 932.9 & 730 & 19.5 & 11.7 & 294.8 & \\
\hline 929.4 & 765 & 19.3 & 11.7 & 294.6 & \\
\hline 926.0 & 795 & 19.0 & 11.8 & 294.3 & \\
\hline 919.2 & 855 & 18.6 & 12.0 & 293.9 & \\
\hline 915.9 & 885 & 18.4 & 11.9 & 293.7 & 299 \\
\hline 909.1 & 950 & 17.8 & 11.8 & 293.1 & \\
\hline 905.8 & 980 & 17.6 & 11.7 & 292.9 & \\
\hline 902.4 & 1010 & 17.5 & 11.9 & 292.8 & \\
\hline 899.1 & 1040 & 17.1 & 11.6 & 292.4 & 299 \\
\hline 895.8 & 1070 & 16.8 & 11.6 & 292.1 & 295 \\
\hline 885.8 & 1170 & 16.1 & 11.3 & 291.3 & \\
\hline 879.3 & 1240 & 15.6 & 10.3 & 290.6 & \\
\hline 876.2 & 1270 & 15.3 & 10.5 & 290.3 & 300 \\
\hline 872.8 & 1292 & 15.2 & 10.0 & 290.2 & 300 \\
\hline 866.3 & 1356 & $I_{4} .4$ & 9.6 & 289.3 & \\
\hline 863.0 & 1388 & 14.7 & 8.9 & 289.5 & 300 \\
\hline 859.8 & 1430 & 114.7 & 7.7 & 289.2 & \\
\hline 853.4 & 1490 & 14.5 & 7.1 & 288.9 & \\
\hline 850.2 & 1520 & 14.6 & 6.5 & 288.9 & 301 \\
\hline 847.1 & 1550 & 14.6 & 5.7 & 288.8 & \\
\hline 843.8 & 1580 & 14.5 & 5.6 & 288.7 & 302 \\
\hline 837.6 & 1640 & 13.8 & 5.5 & 288.0 & \\
\hline 828.2 & 1740 & 13.9 & 5.1 & 288.0 & 303 \\
\hline 825.1 & 1770 & 13.9 & 4.1 & 287.8 & \\
\hline 822.0 & 1800 & 13.9 & 3.8 & 287.8 & \\
\hline 818.9 & 1830 & 13.9 & 3.9 & 287.8 & 304 \\
\hline 815.8 & 1860 & 13.8 & 3.8 & 287.7 & \\
\hline 812.8 & 1890 & 13.7 & 3.8 & 287.6 & \\
\hline 806.6 & 1950 & 13.1 & 4.3 & 287.1 & \\
\hline 803.6 & 1990 & 12.7 & 4.0 & 286.6 & \\
\hline 800.5 & 2020 & 12.7 & 3.9 & 286.6 & 304 \\
\hline 797.5 & 2060 & 12.5 & 4.0 & 286.4 & \\
\hline
\end{tabular}


April 5, 1953. 1300 IST. (contd)

\begin{tabular}{|c|c|c|c|c|c|}
\hline$\left(\begin{array}{c}p \\
(m b\end{array}\right)$ & $\begin{array}{c}h \\
(m)\end{array}$ & $\begin{array}{c}\mathrm{T} \\
\left({ }^{\circ} \mathrm{C}\right)\end{array}$ & $(\mathrm{w} / \mathrm{gm} / \mathrm{kgm})$ & $\left(\mathrm{T}_{\mathrm{A}}\right)$ & $\left(\begin{array}{c}\theta \\
\left({ }^{\circ} A\right)\end{array}\right.$ \\
\hline $\begin{array}{l}794.5 \\
791.5 \\
788.4 \\
785.5 \\
782.5 \\
776.9 \\
774.1 \\
768.3 \\
765.3 \\
759.6 \\
756.6 \\
753.6 \\
750.6 \\
744.9 \\
742.1 \\
736.5 \\
733.7 \\
730.9 \\
728.1 \\
722.6 \\
717.1 \\
714.4 \\
708.9 \\
706.2 \\
703.5 \\
700.8 \\
698.0 \\
689.9 \\
687.1\end{array}$ & $\begin{array}{l}2092 \\
2124 \\
2156 \\
2188 \\
2220 \\
2284 \\
2316 \\
2380 \\
2470 \\
2470 \\
2500 \\
2530 \\
2565 \\
2625 \\
2660 \\
2720 \\
2748 \\
2776 \\
2804 \\
2860 \\
2940 \\
2972 \\
3036 \\
3068 \\
3100 \\
3130 \\
3162 \\
3230 \\
3252\end{array}$ & $\begin{array}{r}12.2 \\
11.9 \\
11.7 \\
11.7 \\
11.3 \\
10.4 \\
10.0 \\
9.4 \\
8.9 \\
9.0 \\
9.4 \\
9.3 \\
9.6 \\
9.7 \\
9.5 \\
9.1 \\
9.0 \\
9.1 \\
9.3 \\
8.5 \\
8.7 \\
8.5 \\
8.3 \\
8.1 \\
8.0 \\
7.8 \\
7.7 \\
7.1 \\
6.8\end{array}$ & $\begin{array}{l}9.5 \\
8.9 \\
9.0 \\
9.1 \\
9.2 \\
8.6 \\
8.4 \\
8.5 \\
5.6 \\
5.2 \\
4.7 \\
2.9 \\
2.5 \\
1.9 \\
1.1 \\
1.1 \\
1.2\end{array}$ & $\begin{array}{l}284.4 \\
284.4 \\
284.2 \\
283.9 \\
283.8 \\
283.8 \\
284.0 \\
283.2 \\
282.9 \\
282.6 \\
282.3 \\
281.8 \\
281.6 \\
281.3 \\
281.1 \\
280.5 \\
280.2\end{array}$ & $\begin{array}{l}304.7 \\
304.7 \\
304.8 \\
305.1 \\
305.0 \\
304.7 \\
305.4 \\
304.5 \\
304.3 \\
304.9 \\
305.7 \\
306.0 \\
305.7 \\
307.5 \\
307.5 \\
307.7 \\
308.0 \\
308.5 \\
309.0 \\
308.6 \\
309.8 \\
309.9 \\
310.5 \\
310.6 \\
310.9 \\
311.0\end{array}$ \\
\hline
\end{tabular}


April 7, 1953. $0950 \mathrm{LST}$. Sounding in cloudy area. Wind $96^{\circ}, 5.5 \mathrm{~m} / \mathrm{sec}$. Location: 20 miles north of Anegada.

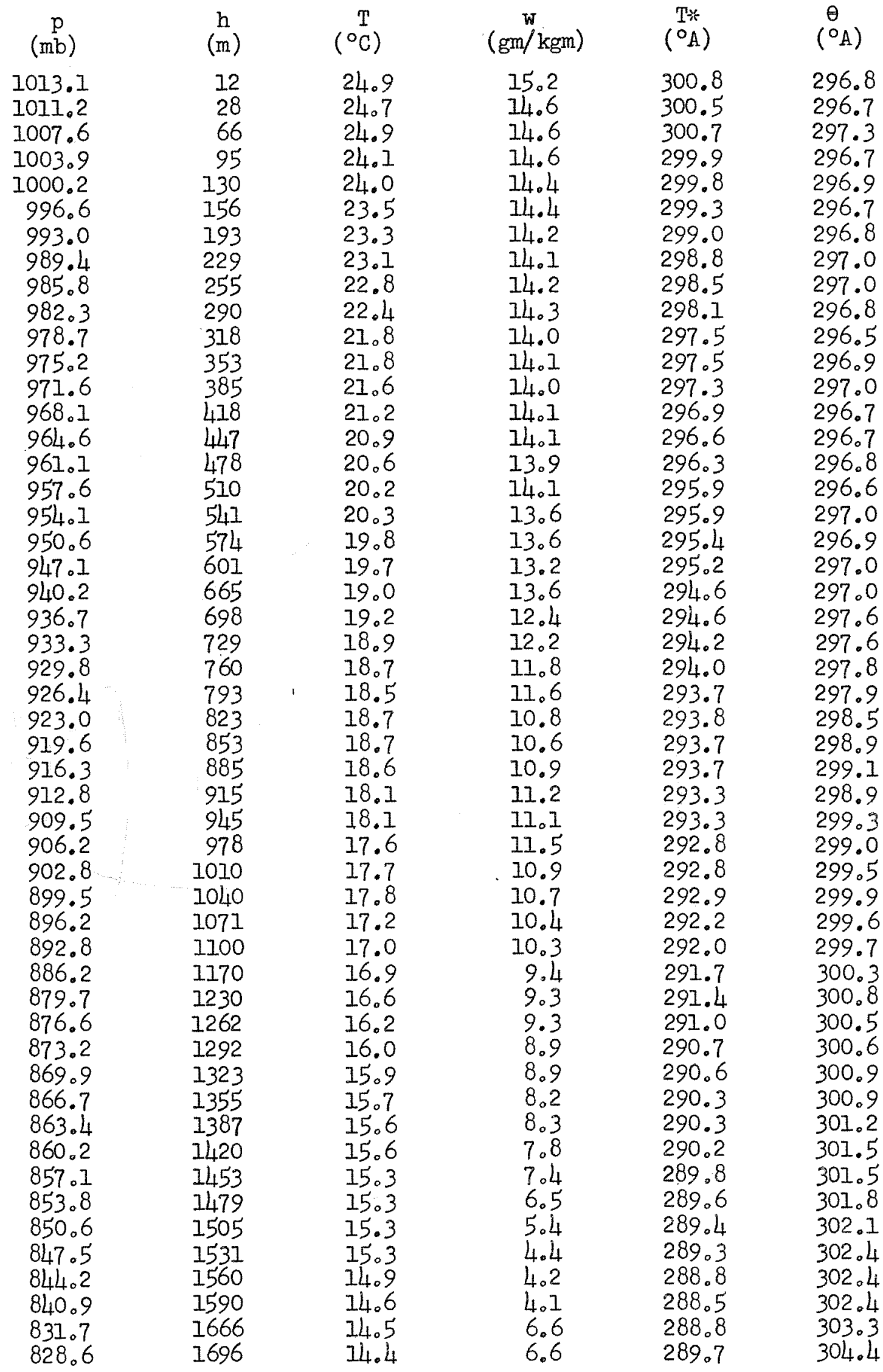


Geophysies Branch, Code 416, Office of Naval Research, Washington 25 , D. C.

Director, Naval Research Laboratory, Attention: Technical Information Officer, Washington $25, \mathrm{D}$. C.

Officer-in-Charge, Office of Naval Research, London Branch Office, Navy No. 100, Fleet Post Office, New York, New York

Office of Naval Research, Branch Office, 346 Broadway, New York 13, New York

Office of Naval Research, Branch Office, 150 Causeway Street, Boston, Massachusetts

Office of Naval Research, Branch Office, Tenth Floor, The John Crerar Iibraxy Building, 86 East Randolph Street, Chicago, Illinois

Office of Naval Research, Branch Office, 1030 East Green Street, Pasadena $I_{\text {, California }}$

Office of Naval Research, Branch Office, 1000 Geary Street, San Francisco, California

Office of Technical Services, Department of Commerce, Washington $25^{\circ}$, D. C.

Armed Services Technical Information Center, Documents Service Center, Knott Building, Dayton 2, Ohio

Assistant Secretary of Defense for Research and Development, Attn: Committee on Geophysics and Geography, Pentagon Building, Washington 25 , D. C.

Department of Aerology, U.S. Naval Post Graduate School, Monterey, California

Aerology Branch, Bureau of Aeronautics (Ma-5), Navy Department, Washington $25, \mathrm{D}$ 。 C.

Mechanics Division, Naval Research Laboratory, Anacostia Station, Washington 20, D. C., Attention: J. E. Dinger, Code 7110

Radio Division I, Code 7150, Naval Research Laboratory, Anacostia Station, Washington 20, D. C. 
Meteorology Section, Navy Electronics Iaboratory, San Diego 52,

Library, Naval Ordnance Laboratory, White Oak, Silver Spring 19, Maryland

Bureau of Ships, Navy Department, Washington 25, D. C., Attention: Code 851 (Special Devices Center)

Bureau of Ships, Navy Department, Washington 25, D. C., Attention: Code 327 (Technical Iibrary)

Chief of Naval Operations, Navy Department, Washington 25,

Oceanographic Division, U. S. Navy Hydrographic Office, Suitland, Maryland

Iibrary, Naval Ordnance Test Station, Inyokern, China Lake, California

Project Arowa, U. S. Naval Air Station, Building R-48,

The Chief, Armed Forces Special Weapons Project, P. 0. Box 2610, Washington, D. C.

Office of the Chief Signal Officer, Engineering and Technical Service, Washington 25, D. C., Attn: SIGGGM

Meteorological Branch, Evans Signal Laboratory, Belmar, New Jersey

Headquarters Quartermaster Research and Development Command, Quartermaster Research and Development Center, U. S. Army, Natick, Massachusetts. Attention: Environmental Protection Division

Office of the Chief, Chemical Corps, Research and Engineering Division, Research Branch, Army Chemical Center, Maryland

Commanding Officer, Air Force Cambridge Research Center, 230 Albany Street, Cambridge, Massachusetts, Attn: ERHS-1

Willow Run Research Center, University of Michigan, Willow Run Airport, Ypsilanti, Michigan, Attn: Shelia Coon, Iibrarian 
Headquarters, Air Weather Service, Andrews Air Force Base, Washington 20, D. C., Attention: Director Scientific Services

Commander, Wright Air Development Center, Wright-Patterson Air Force Base, Ohio, Attention: WCREO-2

Commanding General, Air Force Cambridge Research Center, 230 Albany Street, Cambridge, Massachusetts, Attention: CRHSL

Commanding General, Air Research and Development Command, P. 0. Box 1395, Baltimore 3, Maryland

Department of Meteorology, Massachusetts Institute of Technology, Cambridge, Massachusetts, Attention: H. G. Houghton

Department of Meteorology, University of Chicago, Chicago 37, Illinois, Attention: H. R. Byers

Institute for Advanced Study, Princeton, New Jersey, Attention: J. von Neumann

Scripps Institution of Oceanography, La Jolla, California, Attention: R. Revelle

General Electric Research Laboratory, Schenectady, New York, Attention: I. Langmuir

St. Louis University, 3621 olive Street, St. Louis 8, Missorui, Attention: J. B. Macelwane, S. J.

Department of Meteorology, University of California at Los Angeles, Los Angeles, California, Attention: M. Neiburger

Department of Engineering, University of California at Los Angeles, Los Angeles, California, Attention: L. M. K. Beolter

Department of Meteorology, Florida State University, Tallahassee, Florida, Attention: W. A. Baum

Woods Hole Oceanographic Institution, Woods Hole, Massachusetts, Attention: C. Iselin 
The Johns Hopkins University, Department of Civil Engineering, Baltimore, Maryland, Attention: R. Iong

The Johns Hopkins University, Department of Physics, Homewood Campus, Baltimore, Maryland, Attention: G. Plass

New Mexico Institute of Mining and Technology, Research and Development Division, Socorro, New Mexico, Attention: E. Workman

University of Chicago, Department of Meteorology, Chicago 37, Illinois, Attention: H. Riehl

Woods Hole Oceanographic Institution, Woods Hole, Massachusetts, Attention: A. Woodcock

General Electric Research Laboratory, Schenectady, New York, Attention: V. Schaefer Alaska, Attention: C. T. Elvey

Blue Hill Meteorological Observatory, Harvard University, Milton 86, Massachusetts, Attention: C. Brooks

Laboratory of Climatology, Johns Hopkins University, Seabrook, New Jersey

Department of Meteorology and Oceanography, New York University, New York 53, New York, Attention: B. Haurwitz

Texas $A$ and $M$, Department of Oceanography, College Station, Texas, Attention: J. Freeman, Jr.

Director of Technical Services, Headquarters, Dugway Proving Grounds, Dugway, Utah

Rutgers University, College of Agriculture, Department of Meteorology, New Brunswick, New Jersey

National Advisory Committee of Aeronautics, 1500 New Hampshire Avenue, N.W., Washington 25, D. C.

Travelers Weather Research Center, 700 Main Street, Hartford 15, Conne cticut 
U. S. Weather Bureau, 2lith and M Streets, N. W., Washington 25, D. C., Attention: Scientific Services Division

Air Coordinating Committee, Subcomittee on Aviation Meteorology, Room 2D889-A, The Pentagon, Washington, D. C.

American Meteorological Society, 3 Joy Street, Boston 8, Massachusetts, Attention: The Executive Secretary

Research Professor of Aerological Engineering, College of Engineering, Department of Electrical Engineering, University of Florida, Gainesville, Florida

The Hydrographer, U. S. Navy Hydrographic Office, Washington $25, \mathrm{D}$. C.

Division of Oceanography, U. S. Navy Hydrog raphic Office Washington 25, D. C.

ADDITIONAL DISTRIBUTION LIST

\section{Addressee}

Brookhaven National Laboratory, Upton, L. I., New York, Attention: Meteorology Group

Chemical Corps, Biological Laboratories, Technical Iibrary, Camp Detrick, Frederick, Maryland

Dr: August Raspet, Engineering and Industrial Research Station, Mississippi State College, State College, Mississippi

Dr. E. W. Hewson, Professor of Meteorology, Department of Civil Engineering, University of Michigan, Ann Arbor, Michigan

Dr. Hunter Rouse, Director, Iowa Institute of Hydraulic Research, State University of Iowa, Iowa City, Iowa

Head, Department of Physics, University of New Mexico, Albuquerque, New Mexico

Mr. Wendell A. Mordy, Hawaiian Pineapple Research Institute, Honolulv, Hawaii 
Dr. E. G. Bowen, Chief, Division of Radiophysics, Commonwealth Scientific Industrial Research Organization, University Grounds, Chippendale, N. S. W., Australia

Department of Statistics, Wharton School, University of Pennsylvania, Philadelphia 4, Pennsylvania

Pennsylvania State College, School of Mineral Industries, State College, Pennsylvania, Attention: H. Panosfky

University of Wisconsin, Department of Meteorology, Madison, Wisconsin, Attention: V. Suomi

Institute of Atmospheric Physics, University of Arizona, Tucson 25, Arizona, Attention: J. E. McDonald

Diffusion Project, Round Hill, South Dartmouth, Massachusetts

United States Department of Agriculture, Southern Forest Experiment Station, Federal Building, Asheville, North Carolina, Attention: G. M. Byram

Professor Max A. Woodbury, Logistics Research Project, 707 22nd Street, N.W., Washington, D. C.

Dr. Yale Mintz, Department of Meteorology, University of California, Los Angeles, Califormia 